\title{
Similarities and differences in the
}

historical records of lava dome-building volcanoes: implications for understanding magmatic processes and eruption forecasting

Article

Accepted Version

Creative Commons: Attribution-Noncommercial-No Derivative Works 4.0

Sheldrake, T. E., Sparks, R. S. J., Cashman, K. V., Wadge, G. and Aspinall, W. P. (2016) Similarities and differences in the historical records of lava dome-building volcanoes:

implications for understanding magmatic processes and eruption forecasting. Earth Science Reviews, 160. pp. 240263. ISSN 0012-8252 doi:

https://doi.org/10.1016/j.earscirev.2016.07.013 Available at https://centaur.reading.ac.uk/66290/

It is advisable to refer to the publisher's version if you intend to cite from the work. See Guidance on citing.

To link to this article DOI: http://dx.doi.org/10.1016/j.earscirev.2016.07.013

Publisher: Elsevier

All outputs in CentAUR are protected by Intellectual Property Rights law, including copyright law. Copyright and IPR is retained by the creators or other copyright holders. Terms and conditions for use of this material are defined in 
the End User Agreement.

www.reading.ac.uk/centaur

\section{CentAUR}

Central Archive at the University of Reading

Reading's research outputs online 
1 Title: Similarities and differences in the historical records of lava dome2 building volcanoes: implications for understanding magmatic processes 3 and eruption forecasting.

4

5

6

7

\section{Authors:}

Sheldrake, T. E. a, ${ }^{*} 1$

Sparks, R.S.J. ${ }^{a}$

Cashman, K.V. a

Wadge, G. ${ }^{\text {b }}$

Aspinall, W.P. a

a School of Earth Sciences, University of Bristol, Wills Memorial Building, Queen's Road, Bristol, BS8 1RJ, UK

b Department of Meteorology, University of Reading, Reading, RG6 6AL, UK

*Thomas.sheldrake@unige.ch (corresponding author)

${ }^{1}$ Current address: Section of Earth and Environmental Sciences, University of Geneva, rue des Maraîchers 13, Geneva CH-1205, Switzerland

\section{Abstract:}

A key question for volcanic hazard assessment is the extent to which information can be exchanged between volcanoes. This question is particularly pertinent to hazard forecasting for dome-building volcanoes, where effusive activity may persist for years to decades, and may be punctuated by periods of repose, and sudden explosive activity. Here we review historical eruptive activity of fifteen lava domebuilding volcanoes over the past two centuries, with the goal of creating a hierarchy of exchangeable (i.e., similar) behaviours. Eruptive behaviour is classified using empirical observations that include patterns of $\mathrm{SO}_{2}$ flux, eruption style, and magma composition. We identify two eruptive regimes: (i) an episodic regime where eruptions are much shorter than intervening periods of repose, and degassing is temporally correlated with lava effusion; and (ii) a persistent regime where eruptions are comparable in length to periods of repose and gas emissions do not correlate with eruption rates. A corollary to these two eruptive regimes is that there are also two different types of repose: (i) inter-eruptive repose separates episodic eruptions, and is characterised by negligible gas emissions and (ii) intra-eruptive repose is observed in persistently active volcanoes, and is characterised by 
39 continuous gas emissions. We suggest that these different patterns of can be used to

40 infer vertical connectivity within mush-dominated magmatic systems. We also note

41 that our recognition of two different types of repose raises questions about

42 traditional definitions of historical volcanism as a point process. This is important,

43 because the ontology of eruptive activity (that is, the definition of volcanic activity in

44 time) influences both analysis of volcanic data and, by extension, interpretations of

45 magmatic processes. Our analysis suggests that one identifying exchangeable traits

46 or behaviours provides a starting point for developing robust ontologies of volcanic

47 activity. Moreover, by linking eruptive regimes to conceptual models of magmatic

48 processes, we illustrate a path toward developing a conceptual framework not only

49 for comparing data between different volcanoes but also for improving forecasts of

50 eruptive activity.

51

52 Keywords: Lava-dome volcanoes; Exchangeable behaviours; Persistent; Episodic;

53 Magmatic processes; Forecasting. 
57

58 Volcanic activity can be manifested in many different ways. From a volcanic risk

59 perspective one important variety of eruptive activity is extrusion of lava domes at

60 intermediate and silicic volcanoes. Recurrent hazards associated with dome-

61 building activity include: pyroclastic flows and volcanic blasts associated with the

62 collapse of lava domes and edifice instability; fountain-fed pyroclastic flows

63 associated with Vulcanian to sub-Plinian explosions; and copious tephra fall .

64 Worldwide, such volcanic activity has been responsible for over two thirds of

65 volcanic fatalities since 1600 C.E. (Auker et al., 2013).

66

67

68

69

70

71

72

73

74

75

76

77

78

Within the Smithsonian Global Volcanism Program (GVP) database there are 205 recorded dome-building volcanoes that have been active in the Holocene (Siebert et al., 2010). Of these, 117 have erupted in the last millennium and 89 have erupted since 1900 C.E. (Ogburn et al., 2015). Historical eruptions have lasted many months, years or even decades (Newhall and Melson, 1983; Sparks, 1997; Ogburn et al., 2015). Over historical timescales volcanic activity can be regarded as continuous, albeit fluctuating, but may also include complex episodic and sometimes cyclic fluctuations in intensity, duration, frequency and eruptive style.

Lava dome formation requires particular conditions, which suggests that magmatic processes at dome-building volcanoes have shared characteristics. Specifically, the lavas of dome-building volcanoes have low average eruption rates $\left(\sim 10^{-1}\right.$ to $10^{-2}$ 
$\mathrm{km}^{3} \mathrm{yr}^{-1}$ ) and high viscosities ( $10^{6}$ to $10^{11} \mathrm{~Pa}$ s; Yokayama, 2005) that are commonly associated with high groundmass crystallinity (Cashman, 1992) and, consequently, substantial yield strength (Calder et al., 2015). Nevertheless, dome-building volcanoes can exhibit markedly different eruptive histories, including both the duration of individual eruptive episodes and the potential for explosive activity. This variability reflects the general conceptual tensions in volcanology where: (1) there is a belief that individual volcanoes are unique, as exhibited by the complex nature of their eruptive records, and (2) the concept that eruptive activity is driven by common magmatic processes that produce certain eruptive styles and volcano morphologies (Cashman \& Biggs, 2014).

In this review we identify characteristics of fifteen lava-dome building volcanoes that are similar (exchangeable) or unique (not exchangeable), as well as those that are common only to a sub-group of volcanic records. In volcanology, for example, the concept of exchangeable characteristics can be used to define the common traits for all volcanoes, and to infer the conceptual system that this definition represents. Using this idea, the basic exchangeable characteristics of a volcanic system - implied by the definition of a volcano by Borgia et al. (2010) - are simply magma, eruption, and edifice. We ally to this the idea that the volcanic system (and thus the conceptual construct of volcanism) should be hierarchically organized, such that identifying and characterizing different hierarchies allows individual volcanoes to be distinguished in space and time (Szakács, 2010). For this reason, we develop a hierarchy of different eruptive behaviours using observations from the historical 
102

103

104

105

106

107

108

109

110

111

112

113

114

115

116

117

118

119

120

121 An additional application of our study relates to the implications of a hierarchical

122 construct on the analysis of volcanic datasets. An important issue relates to the

123 concept of volcanic activity as a point-process of discrete events as this influences

124 how magmatic processes are interpreted and how probabilistic forecasts are made. 
125 We also examine the implications of different patterns of eruptive behaviour on

126 forecasting the activity of one volcano using observations from other (perhaps

127 better characterized) volcanoes of the same type. We discuss the issues when

128 selecting evidence to make eruptive forecasts and contextualize this in regards of

129 forecasting the onset of eruptive activity.

130

\section{2. Data}

132

133 The fifteen dome-building volcanoes selected for this review are listed in Figure 1.

134 Our selection is governed by the quality of available data and relevant observations,

135 and guided by the principle that our dataset should contain volcanoes that are well-

136 characterised, have long records of activity and have been recently active. All fifteen

137 volcanoes sit in arc environments, and erupt magmas that are hydrous and

138 intermediate in composition. As volcanic gas emissions are an important aspect of

139 dome-building volcanism, we also include one volcano characterised by persistent

140 gas emissions but no recent eruptive activity.

141

142 To enable comparison of similar dome-building behaviour, we restricted the

143 selection to volcanoes of intermediate composition, thus omitting domes formed by

144 the eruption of crystal-poor rhyolites (e.g., Chaiten 2008: Pallister et al., 2013). To

145 ensure that the eruptive records are complete and not affected by recording biases

146 (Coles and Sparks, 2006; Deligne et al., 2010), we review patterns of eruptive

147 activity only back to 1800 C.E. (Fig. 2), as prior to this date each of the individual 
148 eruptive records is assumed to be incomplete. However, recent advances in the

149 ability to monitor and observe eruptive activity (Cashman and Sparks, 2013) mean

150 that much of the data derive from eruptive activity in the late $20^{\text {th }}$ and early $21^{\text {st }}$

151 centuries. Data sources include eruption databases (Siebert et al., 2010; Ogburn,

152 2013), peer-reviewed publications (e.g., journal articles, professional publications),

153 and observatory data and databases of volcanic unrest (e.g., WOVOdat;

154 http://www.wovodat.org/). Detailed profiles for the volcanoes can be found in the

155 supplementary material.

156

157 Data are collated for two purposes: (i) as empirical evidence of long-term

158 behaviours at dome-building volcanoes, and (ii) as a semi-quantitative measure of

159 their behaviour. Empirical evidence includes observations of phenomenological

160 behaviour, magmatic degassing, and the bulk rock characteristics of erupted

161 products. In contrast to focussed studies at the individual volcanoes, we do not use

162 the observations as direct evidence of specific magmatic processes or characteristics

163 of the respective magmatic systems. Instead, we use them only to subdivide

164 individual volcanoes into groups that reflect their long-term eruptive behaviour. We

165 then examine geophysical (seismicity and deformation) and petrological

166 observations within groups to compare the behaviour of the magmatic systems

167 within and between volcano groups.

168

169

2.1. Phenomenological behaviour 
170 Dome-building volcanoes exhibit a range of effusive and explosive behaviours

171 (Newhall and Melson, 1983; Sparks, 1997; Ogburn et al., 2015). By definition,

172 however, the main eruptive activity involves protracted lava dome extrusion, with

173 extrusive phases that may last from months to many years; our reference volcanoes

174 have also experienced periods of quiescence of months to decades. During times of

175 activity, lava discharge rates can be estimated from ground-based and satellite-

176 based techniques (e.g., Sparks, 1997; van Manen et al., 2010) and used to

177 characterise the intensity of dome growth phases. The effusion rate, together with

178 the magma viscosity, determines whether lava moves away from the vent as a lava

179 flow or builds either an ever-larger dome and talus apron or a near-solid lava spine

180 (Watts et al., 2002; Cashman et al., 2008). Where lava accumulates over the vent, the

181 increase in magma-static head creates a backpressure that can resist extrusion and

182 influence the longer-term dynamics of the magmatic system (Stasiuk et al. 1993;

183 Scandone et al., 2007).

184

185 Phases of extrusive activity can be interspersed with more explosive activity,

186 including Strombolian, Vulcanian and sub-Plinian eruption styles. The intensity and

187 explosivity of eruptive activity can be characterised using phenomenological

188 observations such as ash column height, pyroclastic run-out, tephra fall deposit

189 volumes, some of which can serve as proxies for magnitude, intensity and explosion

190 style (Newhall and Self, 1982). Infrequently, dome-building volcanoes also have

191 large-magnitude explosions, including Plinian eruptions and lateral blasts (Ogburn

192 et al., 2015). 
194 2.2. Magmatic degassing

195 As magma ascends through the crust, volatiles exsolve and rise to the surface

196 (Wallace, 2003; 2005; Oppenheimer et al., 2011). The most abundant volatile

197 species are $\mathrm{H}_{2} \mathrm{O}$ and $\mathrm{CO}_{2}$. $\mathrm{SO}_{2}$, however, is the most commonly monitored volatile

198 because it is a trace gas in the atmosphere and thus its concentration can be readily

199 measured using remote sensing techniques (Rose et al., 2000; Edmonds et al., 2003;

200 Galle et al., 2003; Carn et al., 2013). $\mathrm{SO}_{2}$ fluxes are quantified using ultraviolet

201 absorption spectra and measured in tonnes per day ( $t / d)$; some data for the last few

202 decades are sporadically available for most of the study volcanoes.

203

204 Prior to the development of ultraviolet spectroscopic techniques, gas fluxes were

205 estimated by sampling fumarolic gases (Giggenbach, 1996). Introduction of the

206 correlation spectrometer (COSPEC) in the 1970s allowed $\mathrm{SO}_{2}$ flux measurements,

207 although early measurements were prone to large errors (Oppenheimer et al.,

208 2011). More recently, fluxes have been estimated from differential optical

209 absorption spectroscopy (DOAS; Platt and Stutz, 2008). A major advantage of this

210 method is that spatially distributed multi-beam instruments can provide precise

211 estimates for plume velocity, which significantly reduces measurement errors of

212 flux (Oppenheimer et al., 2011, and references within). Importantly, however,

213 measurements are restricted to sunlight hours only and the quality of gas data from

214 all remote sensing techniques depends on meteorological conditions (e.g., low

215 humidity and no clouds). 
217 Terrestrial-based spectroscopic measurements are not feasible for measuring

218 volatile emissions in major explosive events because abundant ash masks the

219 signals. Consequently, the mass of gas released during large eruption events is

220 measured using satellite-based techniques and then converted to fluxes (Carn and

221 Prata, 2010; Carn et al., 2013).

222

223

224

225

226

227

228

229

230

231

232 Magma rheology is a major determinant of physical behaviour, particularly at

233 shallow depths where flow at the surface may be inhibited by high yield strength.

234 Magma is a multiphase system and consequently its rheology is complex (Mader et

235 al., 2013). Rheology is strongly controlled by the crystallinity of the magmas, which

236 is typically high in intermediate arc magmas. Crystallization is further increased by

237 syn-ascent decompression and degassing and is thus modulated by eruption rate,

238 the pressure of shallow storage prior to eruption, the bulk composition of the 
magma and kinetic factors associated with bubble dynamics (Jaupart and Vergniolle, 1989; Geschwind and Rutherford, 1995; Nakada and Motomura, 1999; Hammer et al., 2000; Cashman and McConnell, 2005; Divoux et al., 2009; Wright et al., 2012).

Exsolved gas can also lead to marked rheological variations as functions of bubble size distribution and bubble content (Manga et al., 1998; Mader et al., 2013). The interplay between magma ascent, decompression, gas exsolution, crystallization and rheology can lead to complex episodic behaviours (e.g., Jaupart and Allegre, 1991; Melnik and Sparks, 1999; Michaut et al. 2013).

\subsection{Geophysical observations}

For each volcano we report common geophysical observations; for consistency, we omit specialised observations (e.g., strain meters, broadband seismicity) made at only one or two volcanoes. Geophysical monitoring observations are susceptible to spatial and temporal biases associated with network capacities and technological constraints at volcano observatories (Sparks et al., 2012). Therefore, it is important to understand these biases and thus the robustness and validity of comparing records. Spatial biases arise from variations in monitoring capacities due to both resource availability and accessibility. Temporal biases are associated with advances in technology that improve observation thresholds and the precision of measurements. These are discussed in more detail with reference to the particular observables.

\subsubsection{Seismicity}


262 Volcanic seismicity can be categorised either by its physical cause, if occurring at the

263 surface (e.g., rockfalls, lahars, pyroclastic flows, etc.), or its waveform and frequency

264 content if originating from within the crust (e.g., high or low-frequency signals;

265 Chouet, 1996; Neuberg, 2000; McNutt, 2005; Chouet and Matoza, 2013). High-

266 frequency (volcano-tectonic) events have recognisable P and S wave first arrivals

267 and are attributed to brittle fracturing related to opening of new pathways for either

268 magma or magmatic fluids (Kilburn, 2003). Low-frequency (long-period and hybrid)

269 events are associated with movement of magma and magmatic fluids (McNutt,

270 2005). Seismicity is most commonly associated with eruptive activity but is also

271 observed during periods of quiescence, that is, when a volcano is in a non-eruptive

272 state, and can be diagnostic of incipient unrest (Phillipson et al., 2013) or post-

273 eruptive tectonic stress recovery (e.g., Barker and Malone, 1991).

274

275 Although seismicity can be characterised using a range of metrics, we focus on the

276 number of events (daily counts) as this is the most commonly recorded observation

277 across the volcanoes in the dataset. We do not compare absolute numbers of seismic

278 events or cumulative seismic moment between volcanoes due to recording biases

279 associated with variations in network capacities and sensitivities (e.g., number of

280 and type of instruments). Instead we compare patterns of total seismicity and the

281 relative frequency of different types of events, primarily long-period and volcano-

282 tectonic earthquakes.

283 
285 The episodic and sometimes repetitive nature of eruptive activity at many dome-

286 building volcanoes commonly manifests as time-varying deformation of the crust

287 that can be monitored at the surface using geodetic techniques. Great variability in

288 instrumentation and network design in the near-field monitoring of ground

289 deformation, however, makes direct comparisons difficult. For this reason, we focus

290 only on far-field deformation ( $>5 \mathrm{~km}$ from the vent). These data also provide useful

291 constraints on deeper magmatic processes. Far-field deformation can be measured

292 by geodetic networks (using GPS), although these measurements require ground-

293 based support and are restricted to only a few of the volcanoes in our dataset. On

294 the other hand, Interferometric Synthetic Aperture Radar (InSAR) techniques using

295 satellite-based instruments provide a global approach for observing far-field

296 deformation (Biggs et al., 2014). By combining observations from these two

297 methods we compare patterns of deformation (i.e. whether the volcano is inflating,

298 deflating or neither) between different volcanoes and relate deformation behaviour

299 to eruptive and non-eruptive phases of activity.

300

301 2.5. Petrology

302 Petrologic data provide information on the homogeneity of the magmatic system,

303 temporal changes of magma composition and the extent to which eruptive activity is

304 influenced by the ascent of discrete magma batches. Of particular interest is

305 evidence for the interaction of different magmas, which can occur at a range of

306 scales. Macroscopic evidence for magma mingling includes enclaves or

307 compositional banding in erupted products. Microscopic details of geochemical 
interactions provide information on the nature and timing of mingling events. Analysis of individual crystals and their melt inclusions provides information on both intrinsic and extrinsic properties (e.g., temperature, pressure and volatile inventories) of magma storage regions (e.g., Nakamura, 1995; Zellmer et al., 2003a; Dirksen et al., 2006; Humphreys et al., 2006; Costa et al., 2013). Finally, petrological analyses and U-series geochemistry can constrain the timescales of magmatic processes (e.g., Volpe and Hammond, 1991; Zellmer et al., 2003b; Cooper and Reid, 2008; Dosseto et al., 2008; Claiborne et al., 2010) that control and sustain eruptive activity at dome-building volcanoes. Quantification of groundmass characteristics (crystallinity, crystal size and shape) can further constrain rates of magma ascent to the surface (e.g., Hammer et al., 2000; Toramaru et al. 2008; Wright et al., 2012).

\section{Patterns of eruptive activity at dome-building volcanoes}

We identify in our dataset two types of long-term behaviour defined by the relative time a volcano remains in a state of eruption or repose (i.e. non-eruption): (1) activity is episodic when time scale of eruption is much less than the time scale of repose; and (2) activity is persistent, when the time scale of eruption is comparable to that of repose (Fig. 3a). Identification of episodic and persistent regimes represents the first sub-level in our hierarchical construct of historical domebuilding volcanism (Fig. 4). 
330 Episodic and persistent behaviour can be manifested over different timescales (Fig.

3314 4) and, over time, individual volcanoes can show both types of behaviour (Fig. 3c).

332 Over the examined time period of the past 200 years, for example, many dome-

333 building volcanoes are characterised by episodic behaviour; however, within that

334 broad description, some have remained in a persistent regime for multiple decades.

335 We characterise these volcanoes as belonging to a mixed regime. Over very long

336 time periods, all the volcanoes in our sample can be viewed as mixed.

337

338 Patterns of $\mathrm{SO}_{2}$ degassing also provide additional insight into long-term patterns of 339 volcanic activity. The largest volumes of $\mathrm{SO}_{2}$ emissions are always associated with 340 major explosive events (e.g., Carn and Prata, 2010; Werner et al., 2013). Two

341 patterns of less energetic degassing can be defined as: $(1) \mathrm{SO}_{2}$ flux that is closely

342 correlated with eruptions (Fig. 3b) and (2) degassing that is not correlated with

343 eruptive activity (Fig. 3a). Correlated degassing is common at volcanoes in an

344 episodic regime; here both gas and magma fluxes decrease with time after an initial

345 (often explosive) maximum (Fig. 5a). Poor correlation between degassing and

346 eruptive activity, in contrast, is typical of persistent activity (Fig. 5b). The

347 correlation of degassing patterns with eruptive behaviour suggests that magmatic

348 degassing constitutes an important distinction between persistent and episodic

349 regimes (e.g., Whelley et al., 2015).

350

351 Finally, we use differences in degassing behaviour to distinguish two states of

352 repose: (1) inter-eruptive repose separates episodic eruptions and is characterised 
353 by negligible degassing (Fig 3a;5a); and (2) intra-eruptive repose occurs in the 354 persistent regime and is characterised by sustained degassing (Fig 3b;5b). We also 355 identify a non-eruptive degassing regime to describe dome-building volcanoes that 356 remain in a state of long-term repose ( decades) characterised by low levels of 357 persistent degassing.

\subsection{Episodic regime}

360 Volcanoes in an episodic regime are characterised by periods of eruptive activity

361 separated by much longer periods of repose. The onset of eruptive episodes is 362 explosive, with high magma discharge rates. Both magma discharge rates and $\mathrm{SO}_{2}$

363 fluxes decrease with time during eruptive periods (e.g., Fig. 6). During eruptive 364 periods, the later stages of activity are typically characterised by low extrusion rates 365 and associated extensive syn-eruptive crystallisation that combine to produce lava 366 spines (e.g., Watts et al., 2002; Cashman et al., 2008). We distinguish two different 367 timescales for episodic activity in historical records (Fig 4): (1) volcanoes where 368 eruptive episodes last several years, and (2) volcanoes where eruptive episodes last 369 a few months at most. These two subgroups can be further distinguished by the 370 homogeneity or heterogeneity of erupted magma compositions.

372 3.1.1. Eruptive episodes lasting years

373 Two volcanoes in this review have experienced episodic activity lasting several 374 years (Fig. 2; UNZ, PEL). In both cases, lava compositions are broadly homogeneous. 375 The duration of inter-eruptive periods of repose is multiple decades or longer. 
(a) Mount Unzen, Japan (UNZ), is a complex dacitic volcano that last erupted near-continuously from 1991-1995 (Fig. 2). No previous historic activity is known although a major sector collapse event of an older dome occurred in 1792 (Ui et al., 2000). Between 1991 and 1995, the composition of eruptive products was $\sim 65$ wt. $\% \mathrm{SiO}_{2}$ (Nakada and Motomura, 1999) and the average lava effusion rate was $\sim 1 \mathrm{~m}^{3} \mathrm{~s}^{-1}$, with higher rates $\left(\sim 4-6 \mathrm{~m}^{3} \mathrm{~s}^{-1}\right)$ during the eruption onset. Extrusion rates generally diminished with time, although a secondary peak was observed in 1993 (Nakada et al., 1999; Fig. 6). SO fluxes averaged $137 \mathrm{t} / \mathrm{d}$, were correlated with extrusion rate and diminished soon after eruptive activity ceased (Hirabayashi et al., 1995).

(b) Mont Pelée, Martinique (Fig. 1), is an andesitic volcano that has erupted infrequently (Fig. 2). The best-recorded eruptive activity occurred in the early part of the $20^{\text {th }}$ century, between 1902-05 and 1929-32 (Lacroix, 1904; Perret, 1937; Tanguy, 1994). During both periods, lava fluxes decreased from $>10 \mathrm{~m}^{3} \mathrm{~s}^{-1}$ to $\sim 1 \mathrm{~m}^{3} \mathrm{~s}^{-1}$ (Tanguy, 2004), with later stages characterised by spine extrusion (Lacroix, 1904; Perret, 1937). The composition of eruptive products from Mont Pelée is quite homogeneous at 62 wt.\% (Fichaut et al., 1989b; Gourgaud et al., 1989; Smith and Roobol, 1990).

\section{3.1.2. Eruptive episodes lasting months}


398 Two volcanoes in this review have experienced eruptive episodes lasting a few 399 months (Fig. 2; RED, AUG). In contrast to the volcanoes in the previous group, the 400 duration of inter-eruptive periods of repose is several years to a few decades. 401 Additionally, lavas of different composition are erupted contemporaneously. 402

(c) Mount Redoubt, USA (RED), is an andesitic volcano that has erupted intermittently on four separate occasions since 1902 (Fig. 2). The most recent eruptive episodes have been in 1989-90 and 2009, each lasting for several months (Miller and Chouet, 1994; Bull and Buurman, 2013). During each eruptive episode eruptive products ranged from 57 to $63 \mathrm{wt} \% \mathrm{SiO}_{2}$, with the later stages involving the more silicic lava (Nye et al., 1994; Coombs et al., 2013). $\mathrm{SO}_{2}$ degassing is highly correlated with periods of eruptive activity. In 1989 -1990, extrusion rates varied from 2.1 to $26 \mathrm{~m}^{3} \mathrm{~s}^{-1}$, with average dome growth occurring at $\sim 5.8 \mathrm{~m}^{3} \mathrm{~s}^{-1}$ (Miller, 1994). Similar extrusion rates were observed in $2009\left(2.2-35 \mathrm{~m}^{3} \mathrm{~s}^{-1}\right)$ although the average rate was slightly higher at $\sim 9.5 \mathrm{~m}^{3} \mathrm{~s}^{-1}$ (Diefenbach et al., 2013). In both cases the initial activity was the most explosive and the extrusion rate declined during eruptive activity (Miller, 1994; Diefenbach et al., 2013). Initial explosive activity in 2009 was associated with the largest $\mathrm{SO}_{2}$ fluxes $(\sim 3000$ to $\sim 17000 \mathrm{t} / \mathrm{d}$ ). Subsequent activity involved more continuous extrusion with $\mathrm{SO}_{2}$ fluxes $\leq 3000$ t/d (Hobbs et al., 1991; Casadevall et al., 1994; Werner et al., 2013). In both 1990 and 2009, it took several years for $\mathrm{SO}_{2}$ fluxes to 
return to undetectable levels after eruptive activity ceased (Doukas, 1995; Werner et al., 2013).

422

(d) Mount Augustine, USA (AUG), is an andesitic volcano that has had nine known eruptive episodes since 1812, with the most recent in 1976, 1986 and 2006 (Fig 2), each lasting for several months (Swanson and Kienle, 1988; Power et al., 2006; Power and Lalla, 2010). The composition of the erupted magma has ranged from 56 to $64 \mathrm{wt} . \% \mathrm{SiO}_{2}$, with more silicic magma preferentially erupted later in each eruptive episode (Harris, 1994; Roman et al., 2006; Larsen et al., 2010). During the 2006 eruptive activity, magma fluxes varied from 2 to $22 \mathrm{~m}^{3} \mathrm{~s}^{-1}$ (Coombs et al., 2010). Notably, in contrast to other volcanoes in episodic regimes, the final stages of eruptive activity at Augustine in 2006 were characterised by elevated discharge rates and the formation of lava flows, although discharge rates were still lower than at the onset of eruptive activity (Coombs et al., 2010). Magmatic degassing is correlated with eruptive activity, with the largest fluxes commonly associated with explosive activity (Stith et al., 1978, Rose et al., 1988; McGee et al., 2010). In 2006, however, the highest $\mathrm{SO}_{2}$ fluxes ( $\left.\sim 9000 \mathrm{t} / \mathrm{d}\right)$ were associated with a brief hiatus in eruptive activity, although $\mathrm{SO}_{2}$ fluxes were high ( $\sim 3000 \mathrm{t} / \mathrm{d})$ throughout the eruptive episode (McGee et al., 2010), and it took 1-2 years after the end of eruptive episodes in 1986 and 2006 for $\mathrm{SO}_{2}$ fluxes to return to undetectable levels (Symonds et al., 1990; Doukas, 1995; McGee et al., 2010). 


\section{$444 \quad$ 3.2. Persistent regime}

445 We identify eight volcanoes in this review that have remained in a persistent regime

446 for decades or longer. Volcanoes in a persistent regime exhibit broadly consistent

447 behaviour associated with stable long-term lava fluxes. For example, although rates

448 of lava effusion at Bezymianny, Kamchatka, have varied over the short term, they

449 have been approximately constant over the past several decades (Fig. 5). The

450 eruptive activity of an individual volcano can also show 'typical' (repeatable)

451 patterns of behaviour, as illustrated by Santiaguito, Guatemala, where typical

452 behaviour comprises "small to moderate explosions of steam and ash, small

453 pyroclastic flows... and effusion of blocky lava domes and flows" (Scott et al., 2012).

454 Typical intermittent behaviour at Merapi, Indonesia, in contrast, is characterised by

455 eruptive activity that is "low in explosivity with VEI-3 or less ... [that] involve the

456 formation of a lava dome" (Ratdomopurbo et al., 2013).

457

458 We distinguish two different variants of long-term persistent behaviour (Fig. 4).

459 Firstly, there are volcanoes that have remained in a persistent regime at least the

$46019^{\text {th }}$ century. These volcanoes produce lavas with an approximately constant bulk

461 composition. Secondly, there are volcanoes that have entered a persistent regime

462 following a long period of in a state of repose. Volcanoes in this group typically have

463 bulk compositions that show a decrease in $\mathrm{SiO}_{2}$ content with time. 
466 Four of the dome-building volcanoes in this study have been in a persistent regime

467 throughout the $19^{\text {th }}, 20^{\text {th }}$ and $21^{\text {st }}$ centuries; these volcanoes are characterised by

468 frequent, intermittent phases of dome-growth (Fig. 2; MER, COL, LAS, SHI). The style

469 of eruptive activity is generally consistent through time and characterised by

470 definable 'typical' behaviour, except for rare large-magnitude explosions (Fig. 2).

471 Interestingly, these explosive events commonly involve magma that is more mafic

472 than erupted during the effusive phases. Activity at each volcano is described in

473 detail below.

474

475

(a) Merapi, Indonesia (MER), is a basaltic andesite volcano that has been in an eruptive state every few years since at least the $18^{\text {th }}$ century. Eruptive activity is characterised by minor explosions associated with the extrusion of viscous lava domes and coulées that can collapse to form block-and-ash pyroclastic flows (Voight et al., 2000). Lava extrusion rates are approximately constant over historical records at $\sim 0.5 \mathrm{~m}^{3} \mathrm{~s}^{-1}$ (Siswowidjoyo et al., 1995). Persistent effusive activity has been punctuated by at least two major explosions that have produced high-energy pyroclastic density currents (Surono et al., 2012). The bulk rock lava composition ranges from 52 to 56 wt. $\% \mathrm{SiO}_{2}$ (Andreastuti et al., 2000; Gertisser and Keller, 2003) and shows no temporal trend, although explosive events appear to involve deeply sourced, volatile-rich magmas (Costa et al., 2013), which may be more mafic (Gertisser and Keller, 2003). $\mathrm{SO}_{2}$ degassing is continuous with fluxes between 50 and 250 t/d (Humaida, 2008), although instantaneous fluxes can be much 
larger ( 10,000’s t/d) during major explosive events (Surono et al., 2012). Importantly, $\mathrm{SO}_{2}$ fluxes and eruptive activity appear decoupled, with $\mathrm{SO}_{2}$ flux peaks observed during inter-eruptive periods, and sometimes associated with ash venting (Ratdomopurbo et al., 2013).

493

(b) Colima, Mexico (COL), is an andesite volcano that has been erupting intermittently since the $18^{\text {th }}$ century. Periods of intra-eruptive repose normally last on the order of years, although longer periods without apparent eruptive activity have followed major explosive events in 1818 and 1913. These longer periods of repose probably involved endogenous growth below the crater rim (Robin et al., 1991; González et al., 2002), so we infer that Colima remained in a persistent regime during post-explosion periods. Eruptive activity is characterised by lava dome extrusion, Vulcanian explosions and occasional block-and-ash flows (Zobin et al., 2002). Shortterm lava effusion rates vary from $<1$ to $>5 \mathrm{~m}^{3} \mathrm{~s}^{-1}$ (Varley et al., 2010), but long-term averages are poorly constrained. The lava composition ranges from 59 to 62 wt.\% $\mathrm{SiO}_{2}$ with no clear temporal trend (Luhr and Carmichael, 1980; 1990; Savov et al., 2008), except that products of major explosive events are more mafic $\left(\mathrm{SiO}_{2}=55-58\right.$ wt.\%; Luhr and Carmichael, 1990; Reubi and Blundy, 2009; Crummy et al., 2014). $\mathrm{SO}_{2}$ degassing is continuous, with fluxes typically between 50 and 1000 t/d (Casadevall et al., 1984; Engberg, 2009), although sometimes as high as 5000 t/d (Taran et al., 2002; Varley and Taran, 2003). Magmatic degassing appears decoupled from eruptive 
activity (Zobin et al., 2008), but the largest $\mathrm{SO}_{2}$ fluxes are associated with more explosive events (Taran et al., 2002).

514

515 (c) Lascar, Chile (LAS), is an andesitic volcano that has been erupting

516 intermittently at yearly to decadal timescales throughout much of its history.

517 Lava dome growth has been confined within a large summit crater. Four

518 periods of near-continuous dome growth occurred between 1984 and 1993;

519 each culminated in lava dome subsidence and explosive events, including a

520 Plinian explosion in April 1993 (Matthews et al., 1997). Long-term lava

521 extrusion rates are poorly constrained but are likely to be $<0.1 \mathrm{~m}^{3} \mathrm{~s}^{-1}$

522 (Matthews et al., 1997). Since 1993, activity has comprised episodic

523 Vulcanian explosions that have decreased in both intensity and frequency;

524 the last explosion occurred in 2007. Juvenile pyroclasts from 1993 can be

525 separated by composition into two groups: $57.6-58.7$ or $60.4-61.4$ wt.\% $\mathrm{SiO}_{2}$

526 (Matthews et al., 1999); similarities to previously erupted lavas (Deruelle,

527 1985) suggest that the magma composition has remained constant

528 throughout its history. Lascar has exhibited continuous fumarolic activity

529 (Casertano, 1963; Gardeweg \& Medina, 1994) with recent $\mathrm{SO}_{2}$ fluxes

530 sustained between 150 and 940 t/d (Henney et al., 2012, Menard et al.,

531 2014). During more explosive activity, fluxes have reached 2300 t/d (Andres

532 et al., 1991; Mather et al., 2004). $\mathrm{SO}_{2}$ fluxes have shown an irregular pattern

533 of degassing during periods of intra-eruptive repose and therefore appear

534 decoupled from magma flux (Menard et al., 2014). 
(d) Shiveluch, Russia (SHI) is an andesitic volcano that has been erupting intermittently since a major explosive event in 1854. Even prior to 1854 , sparse observations suggest that periods of repose lasted no more than a few decades. Recent phases of eruptive activity have varied in duration from months to several years, and Shiveluch has been in a near-continuous eruptive state since 2000 (Belousov, 1995; Zharinov and Demyanchuk, 2008). Between 1980 and 2007 the average lava discharge rate was $\sim 0.4$ $m^{3} s^{-1}$, although fluxes fluctuated considerably (Zharinov and Demyanchuk, 2008). Explosive activity has been of variable magnitude, with major Plinian events in 1854 and 1964 (Belousov, 1995). The eruptive products contain 56-62 wt.\% $\mathrm{SiO}_{2}$ and show no temporal trends (Dirksen et al., 2006; Humphreys et al., 2006; Gorbach and Portnyagin, 2011). Fumarolic activity

\section{3.2.2. Long-duration repose preceding a long-term persistent regime}

553 Two volcanoes in this study have initiated persistent behaviour after explosive 554 eruptions that followed a long period in a state of repose $(\sim$ millennia; Fig. 2 ; SAN, 555 BEZ). The onset of a persistent regime at these volcanoes is characterised by Plinian 556 and lateral blast explosions. In contrast to the previous group, the most evolved 
pyroclasts in this group are associated with major explosive events; the $\mathrm{SiO}_{2}$ content

558 of subsequent lavas decreases systematically through time.

559

560

(e) Santiaguito (Santa Maria), Guatemala (SAN), is a dome complex that has been active since 1922; effusive activity followed the Plinian eruption of its parent volcano, Santa Maria, in 1902 (Rose, 1972). Effusive activity has been nearly continuous at long-term rates of $\sim 0.46 \mathrm{~m}^{3} \mathrm{~s}^{-1}$, with marked fluctuations that have been classified into eight distinct phases (Rose, 1973; Harris et al., 2003; Scott et al., 2013). Each phase has initiated with high rates (0.5-2.1 $\mathrm{m}^{3} \mathrm{~s}^{-1}$ ) and has been followed by low, sustained extrusion rates of $<0.2 \mathrm{~m}^{3} \mathrm{~s}^{-1}$ (Harris et al., 2003; Ebmeier et al., 2012). The lavas are dacitic to silicic andesite in composition, with $\mathrm{SiO}_{2}$ contents that have decreased systematically from $\sim 66$ to $\sim 62 \mathrm{wt} . \%$ since 1922 . $\mathrm{SO}_{2}$ degassing is continuous with average fluxes between 80 and 120 t/d (Andres et al., 1993; Rodríguez et al., 2004).

572

(f) Bezymianny, Russia (BEZ), is an andesite volcano that has been erupting near-continuously to intermittently since a lateral blast and associated sector collapse in 1956 (Belousov et al., 2007). Between 1956 and 1977, eruptive activity was limited to periods of endogenous lava dome growth associated with sustained fumarolic activity (Gorshkov, 1959; Bogoyavlenskaya et al., 1985; Belousov, 1996). After 1977, dome growth occurred exogenously and included occasional explosions (van Manen et al., 2010). More recently, 
580

581

582

583

584

585

586

587

588

589

590

591

592

593

594

595

596

597

598

599 The eruptive behaviour at these volcanoes varies markedly, with persistent activity

600

601

602

eruptive phases have decreased in duration and have become increasingly explosive (West, 2013). The long-term average extrusion rate was $0.6 \mathrm{~m}^{3} \mathrm{~s}^{-1}$ between 1956 and 1976 (Belousov et al., 2002) and 1993 to 2008 (van Manen et al., 2010). Since 1956 the eruptive products have become steadily less evolved with time, varying from 60.4 to 56.8 wt. $\% \mathrm{SiO}_{2}$ (Bogoyavlenskaya et al., 1985; Turner et al., 2013). $\mathrm{SO}_{2}$ degassing has been sustained. Fluxes have been measured at 140 to $280 \mathrm{t} / \mathrm{d}$ during three campaigns conducted during periods of low eruptive activity (Lopez et al., 2013). These measurements are not sufficient to assess relations between degassing and magma discharge.

\subsection{Mixed eruptive regime}

Persistent and episodic regimes can manifest over different timescales at individual volcanoes. Consequently, the historical records of some dome-building volcanoes exhibit patterns of eruptive activity that are characteristic of both regimes: they exhibit persistent behaviour over several decades but are also characterised by long periods of inter-eruptive repose. We identify four volcanoes that fit this category and define them as 'mixed' regime volcanoes (Fig. 2; MSH, SHV, TUN, POP). over short timescales but episodic activity over timescales of decades to centuries and persistent activity over shorter timescales. Mixed activity is sufficiently varied, however, that it cannot be considered exchangeable. For example, Mount St Helens 
603 showed persistent activity throughout most of the 1980's with degassing that was

604 well correlated temporally with lava extrusion. Tungurahua, in contrast, has

605 remained in a persistent regime since 1999, with degassing that has been poorly

606 correlated with lava extrusion. A common observation at all of these volcanoes,

607 however, is intermittent ash venting.

608

609

610

(a) Mount St. Helens, USA (MSH), is a dacitic volcano that has experienced two eruptive episodes in recent times: 1980 to 1986, and 2004 to 2008 (Swanson and Holcomb, 1990; Scott et al., 2008), following an inter-eruptive period of repose lasting 136 years (Fig. 2). Eruptive activity in 1980 initiated with endogenous growth of the edifice (Lipman and Mullineaux, 1981) that caused a major flank collapse accompanied by sub-Plinian explosive activity (Voight et al., 1983; Glicken, 1998). This was followed by sub-Plinian to Vulcanian explosions in the summer of 1980 that steadily decreased in magnitude and duration (Scandone and Malone, 1985). Subsequent effusive activity transitioned between discrete and continuous eruptions of variably crystalline lavas (Cashman, 1992). Between 1980 and 1986, extrusion rates varied from 1.4 to $40 \mathrm{~m}^{3} \mathrm{~s}^{-1}$, with a long-term average of $\sim 0.4 \mathrm{~m}^{3} \mathrm{~s}^{-1}$ (Anderson and Fink, 1990; Swanson and Holcomb, 1990). Renewed continuous effusion in 2004 occurred at rates that decreased steadily until 2008 , with a maximum of $<5.9 \mathrm{~m}^{3} \mathrm{~s}^{-1}$ and a long-term average of $0.1 \mathrm{~m}^{3} \mathrm{~s}^{-1}$ (Schilling et al., 2008; Major et al., 2009). Between 1980 and 1986 magma compositions were broadly homogeneous at 62-64 wt.\% $\mathrm{SiO}_{2}$ (Cashman, 

erupted between 2004 and 2008 were similarly homogenous at 63-65 wt.\% $\mathrm{SiO}_{2}$ (Blundy et al., 2008; Pallister et al., 2008). During both eruptive periods, degassing was continuous and largely coupled with magma extrusion. The largest $\mathrm{SO}_{2}$ fluxes were associated with explosive activity in the early 1980's, when they frequently exceeded $1000 \mathrm{t} / \mathrm{d}$ (Gerlach and McGee, 1994). The lowest $\mathrm{SO}_{2}$ fluxes $(\sim 70 \mathrm{t} / \mathrm{d})$ were associated with the dome-building activity in 1982-86 and 2004-2008 (Gerlach and McGee, 1994; Gerlach et al., 2008). Following the cessation of each eruptive episode, $\mathrm{SO}_{2}$ fluxes decreased rapidly to negligible levels. In the 1990's, however, detectable gas emissions (Gerlach et al., 2008) were observed concurrently with elevated shallow VT 638

(b) Soufrière Hills Volcano, Montserrat (SHV), is an andesitic volcano that erupted in 1995 following several centuries of no eruptive activity. Since 1995 it has exhibited intermittent activity with five phases of eruptive activity lasting several months to years (Young et al., 1998; Sparks and Young, 2002; Wadge et al., 2010; 2014), with the last phase ending in 2010. The eruptive activity has included lava dome extrusion, block-and-ash flows and Vulcanian explosions; periods of repose have been characterised by ash venting and continuous degassing (Wadge et al., 2014). The time-averaged lava extrusion has been $3 \mathrm{~m}^{3} \mathrm{~s}^{-1}$, although rates exceeding $10 \mathrm{~m}^{3} \mathrm{~s}^{-1}$ have 

58 to 62 wt.\% (Murphy et al., 2000; Zellmer et al., 2003b; Barclay et al., 2010; Christopher et al., 2014). The average $\mathrm{SO}_{2}$ emission rate from 1995 to 2010 was $\sim 530$ t/d (Christopher et al., 2010) and largely decoupled from eruptive activity (Christopher et al., 2010; Edmonds et al., 2010; Christopher et al., 2015). Soufrière Hills Volcano continues to degas at 430 t/d (Christopher et al., 2015). During periods of intra-eruptive repose, peaks in degassing of several thousand $\mathrm{t} / \mathrm{d}$ have been associated with bursts in seismicity (VTs) and are sometimes accompanied by ash venting (Cole et al., 2014).

658

(c) Tungurahua, Ecuador (TUN), erupted in 1999 following 81 years of no eruptive activity. Slow lava extrusion and frequent explosive activity during phases of eruptive activity have limited lava dome growth. Between 1999 and 2006 Tungurahua alternated between explosive (Strombolian to Vulcanian) eruptions and relatively quiet periods dominated by ash venting and fumarolic activity. The most explosive activity occurred during July and August 2006 (Arellano et al., 2008), after which activity returned to frequent low-intensity Strombolian explosions (Steffke et al., 2010). Whilst the magma supply rate has varied over timescales of months (Wright et al., 2012), the long-term emission rate of ash has been approximately constant at $>0.2$ $\mathrm{m}^{3} \mathrm{~s}^{-1}$, and possibly $>0.4 \mathrm{~m}^{3} \mathrm{~s}^{-1}$ (Le Pennec et al., 2012). The eruptive products have compositions of 56-59 wt.\% $\mathrm{SiO}_{2}$ and show no systematic variation with time or eruptive style (Samaniego et al., 2011), except that major explosive 
events in 1866 and 2006 have included a minor dacitic component (Samaniego et al., 2011). Between 1999 and 2006, SO 2 fluxes varied from several hundred to thousands of $\mathrm{t} / \mathrm{d}$; degassing has been largely decoupled from eruptive activity (Arellano et al., 2008), although since 2006 daily $\mathrm{SO}_{2}$ fluxes have decreased and appear to be better correlated with eruptive activity.

(d) Popocatépetl, Mexico (POP), has experienced several periods of eruptive activity in the $20^{\text {th }}$ century. Most recently, eruptive activity was renewed in 1994 and has involved repeated periods of dome growth that have culminated in explosive eruptions and dome collapse. Extrusion rates have ranged from 0.5 to $4.1 \mathrm{~m}^{3} \mathrm{~s}^{-1}$ during dome-growth in 1996 and 1997; the long-term average has been $0.24 \mathrm{~m}^{3} \mathrm{~s}^{-1}$ (Delgado-Granados et al., 2001). Prior to 1995, Popocatépetl last erupted between 1920 and 1927 (DelgadoGranados et al., 2001) followed by several decades of minor degassing and ash venting (Brennan, 2007). Pyroclasts erupted between 1996 and 1998 ranged in bulk composition from $\sim 59$ to $64 \mathrm{wt} \% \mathrm{SiO}_{2}$ (Athanasopoulos, 1997; Straub and Martin-Del Pozzo, 2001), with all compositions erupted contemporaneously (Witter et al., 2005). In 1994, average $\mathrm{SO}_{2}$ fluxes were several thousand t/d. Similarly high $\mathrm{SO}_{2}$ fluxes $(30,000-50,000 \mathrm{t} / \mathrm{d})$ marked explosive activity between 1996 and 1998 (Goff et al., 1998; DelgadoGranados et al., 2001). DOAS measurements of the plume in 2006 provide an 
average flux of $2450 \mathrm{t} / \mathrm{d}$, with large daily variations not always associated with eruptive activity (Grutter et al., 2008).

696

697

698

699

700

701

702

703

704

705

706

707

708

709

710

711

712

713 Geochemical analysis of erupted products and geophysical observations can provide

714 semi-empirical evidence for different magmatic processes. We summarise these

715 data for the fifteen dome-building volcanoes, with a particular focus on systematic

716 variations in the behaviour of volcanoes in the different regimes. 
719 Evidence of mixing and mingling between different batches of magma are observed 720

\subsection{Interaction of magmas} in all 14 volcanoes in our database that have erupted in the $20^{\text {th }}$ century (Table 2 and references therein). Different magma batches typically vary in composition, although interactions are also observed between magmas or melts that are similar in composition but differ in temperature and crystallinity (Cashman and Blundy, 2013; Costa et al., 2013; Troll et al., 2013). Evidence for magma interaction over short timescales (days to years) is ubiquitous and includes: (1) disequilibrium mineral assemblages; (2) disequilibria between mineral assemblages and matrix glass; and (3) phenocryst zoning (Table 2). Zoning patterns, in particular, provide evidence that magma mixing is sustained over a range of times. Discrete magma mixing events may be associated with single explosive events (Pallister et al., 2008; Samaniego et al., 2011; Scott et al., 2013) or individual phases of effusive activity lasting months (Dirksen et al., 2006). Frequent and near-continuous magma mixing may accompany sustained lava effusion (Nakamura, 1995; Barclay et al., 2010; Turner et al., 2013).

The degree of mixing ranges from contemporaneous eruption of different magma compositions to the eruption of lavas that are homogeneous in bulk composition but heterogeneous on a thin section scale. Evidence for incomplete mixing includes banded lava or pumice, or mafic enclaves in more silicic host lavas. Where incomplete mixing is observed, historical activity tends to be episodic with moderate to long periods of inter-eruptive repose. Persistent activity, in contrast, 
tends to produce homogeneous lavas; here evidence for magma mixing is preserved only at the micro-scale, in melt inclusions, disequilibrium mineral assemblages, polymodal mineral compositions, and phenocryst zonation (Table 2).

\subsection{Geophysical observations}

\subsubsection{Seismicity}

Similar patterns of seismicity are observed across all the volcanoes in this review, with no apparent correlation with eruptive regime. Most volcanic earthquakes occur prior to and during eruptive activity. Renewed eruptive activity is generally preceded by elevated VT seismicity, with elevated LP seismicity immediately prior to eruption initiation. Levels of LP seismicity are highest at volcanoes in persistent regimes where degassing rates are high (e.g., Lascar, Popocatépetl; Asch et al., 1996). Hybrid events (LP seismicity with clear P \& S wave arrivals) are commonly associated with dome-growth (e.g., Miller et al., 1998; Umakoshi et al., 2008).

Once a volcano has remained in a state of repose for more than a few months, the level of seismicity decreases, although episodic increases in VT seismicity are common and are often associated with elevated degassing and ash venting (Mastin, 1994; Ratdomopurbo et al., 2013; Budi-Santoso et al., 2013; Sernageomin, 2013;

Cole et al., 2014). Seismic crises can occur during inter-eruptive repose; these may last for several months to several years with multiple felt earthquakes and no eruption of magma (Japan Meteorological Agency, 1996, Young et al., 1998). 

an episodic regime than at those in a persistent regime (Table 3), although this

\subsubsection{Deformation}

Geodetic measurements of far-field deformation are more common at volcanoes in apparent correlation could be coincidental, since many of the volcanoes in our dataset that exhibit episodic behaviour are located in developed countries, which tend to have well-established monitoring and research capabilities (e.g., USA and Japan). Alternatively, volcanoes in a persistent regime may lack far-field observations because only near-field observations are required for short-term forecasting. At episodic volcanoes, periods of repose may show inflation, whereas deflation is primarily associated with phases of dome growth (Table 3). The timescales of inflation vary from years (e.g., Augustine, Redoubt; Cervelli et al., 2010; Grapenthin et al., 2013a) to decades (e.g., Augustine, Unzen; Kohno et al., 2008; Lee et al., 2010). Soufrière Hills Volcano, which has remained in a persistent regime since 1995, also exhibits cycles of far-field inflation and deflation coincident with eruptive and non-eruptive cycles of months to years (Odbert et al., 2014a). Where persistent behaviour includes short phases of lava effusion and explosive eruption (e.g., Bezymianny, Merapi, Colima), InSAR measurements suggest negligible far-field deformation (Chaussard et al., 2013; Grapenthin et al., 2013b).

\section{Conceptual magmatic models for dome-building volcanism}

The interpretation of magmatic processes and their relation to volcanism requires a conceptual model for volcanic activity. From this perspective, understanding the 
geometry of pre-eruptive magma storage is critical. A widespread, but not universal, observation about dome-building volcanoes is that magma is supplied from storage regions in the shallow crust (Table 5 and references therein), which has stimulated models of eruptive activity modulated by shallow magma chambers (Gourgaud et al., 1989; Murphy et al., 2000; Mora et al., 2002; Humphreys et al., 2008; Roberge et al., 2009; Larsen et al., 2010; Samaniego et al., 2011; Shcherbakov et al., 2011;

Coombs et al., 2013; Turner et al., 2013). There is also evidence, however, for deeper levels of magma storage, including mid- to lower crustal earthquakes associated with volcanism (McNutt, 2005; Power et al., 2013), deep sources of deformation (Pritchard and Simons, 2002; Elsworth et al., 2008), and deep sources of gas (Troll et al., 2013; Hautmann et al., 2014; Christopher et al. 2015). Petrological and geochemical data help to quantify the importance of deep igneous processes (Hildreth, 2004; Troll et al., 2013; Edmonds et al., 2014), including mineral assemblages that record multiple crystallisation depths (Matthews et al., 1994; Martel et al., 1998; Scott et al., 2012; Cashman and Blundy, 2013; Turner et al., 2013) and geochronology evidence for long crustal residence times (Volpe and Hammond, 1991; Zellmer et al., 2003b; Cooper and Reid, 2008; Dosseto et al., 2008; Claiborne et al., 2010). Finally, tomographic images of arc volcanoes suggest magma storage occurs at different depths throughout the crust (e.g., Koulakov et al., 2013).

Here we place geochemical and geophysical evidence for transcrustal magmatic systems in the context of our categorisation of temporal variations in the historical records of lava dome-building volcanoes. Specifically, we address the question of the 
extent to which observed regimes are consistent with non-linear processes

811 associated with a shallow magma chamber, or whether they require involvement of

812 vertically extensive crustal processes. Importantly, our aim is not to attribute the

813 behaviour of an individual volcano or eruptive event to either paradigm, but instead

814 to investigate the extent to which different eruptive regimes may reflect

815 fundamentally different subsurface conditions, at least with regard to the extent and 816 connectivity of individual magma lenses. We conclude that whilst storage of magma

817 in the upper crust exerts an important control on when and what eruptive activity

818 occurs, over historical timescales different patterns of volcanism can be better

819 ascribed to a conceptual model based on complex behaviours of vertically extensive 820 magma storage regions.

821

\section{5.1. Shallow chamber paradigm}

823 A common model for eruptive activity at dome-building volcanoes is a shallow melt-

824 dominated magma chamber that is replenished from depth and periodically

825 discharges magma (Fig. 7). In this paradigm, intrusion of mafic magma from depth is

826 assumed to trigger the eruption of shallow magma bodies (Gourgaud et al., 1989;

827 Murphy et al., 2000; Mora et al., 2002; Humphreys et al., 2008; Roberge et al., 2009;

828 Larsen et al., 2010; Samaniego et al., 2011; Shcherbakov et al., 2011; Coombs et al.,

829 2013; Turner et al., 2013). The concept of mafic triggers derives primarily from

830 near-ubiquitous evidence for magma mixing (Table 2). Intruding mafic magma also

831 provides an explanation for observations of excess $\mathrm{SO}_{2}$ (that is, emission of $\mathrm{SO}_{2}$ in

832 excess of amounts dissolved in the erupted magma; Andres et al., 1991; Wallace, 
833

2003; Shinohara, 2008; Christopher et al., 2010; Wallace and Edmonds, 2011), as

$834 \mathrm{SO}_{2}$ is much more soluble in mafic magmas that in silicic magmas (Wallace, 2005).

835 Petrologic evidence for shallow magma storage comes from saturation pressures

836 recorded in melt inclusions, as well as phase assemblages consistent with storage

837 pressures $\leq 200 \mathrm{MPa}$ (e.g., Moore and Carmichael, 1998; Blundy and Cashman,

838 2001; Couch et al., 2001).

839

840 The modulating effect of shallow magmatic systems on eruptive processes is

841 supported by geophysical data. Deflation during eruptive periods can be related to

842 magma discharge from upper- or mid-crustal magma chambers (Nishi et al., 1999;

843 Elsworth et al., 2008; Cervelli et al., 2010; Mattioli et al., 2010; Grapenthin et al.,

844 2013a). Furthermore, most seismicity associated with unrest and eruptive activity is

845 restricted to depths of $<10$ kilometres (Ratdomopurbo and Poupinet, 2000; Moran

846 et al., 2008; Power and Lalla, 2010; Thelan et al., 2010; Petrosino et al., 2011).

847 Seismicity is commonly inferred to record the stress effects of the formation of

848 magma transport pathways (Kilburn, 2003; Scandone et al., 2007) and rise of

849 magmatic fluids from shallow magma chambers (Neuberg, 2000; McNutt, 2005;

850 Chouet and Matoza, 2013). Shallow seismicity is also associated with shallow

851 magma intrusion (Moran et al., 2011), pressurisation and pre-eruptive inflation.

852

853 Patterns of recharge have been used to explain pulsatory and cyclic behaviour

854 (Melnik and Sparks, 1999; Barmin et al., 2002). Indeed it is likely that volcanism is

855 modulated, jointly, by different parts of the volcanic system, including shallow 
856

857

858

859

860

861

862

863

864

865

866

867

868

869

870

871

872

873

874

875

876

877

878 magma chambers. However, because the mechanism for replenishment in the shallow chamber paradigm is poorly understood, it cannot completely explain the hierarchy of common behaviours and similar patterns and styles of eruptive activity.

\subsection{Transcrustal destabilisation}

A shallow magma chamber can be envisaged as the upper manifestation of a much larger transcrustal system (Marsh, 2000; Cañón-Tapia and Walker, 2004), which may extend throughout the crust and even into the mantle (Fig. 8). Such a conceptual model implies that mechanisms for unrest and eruption may involve more complex processes than discrete intrusions. Specifically, magmatic systems can be viewed as comprising extensive bodies of crystal-rich magma (mush) with interspersed lenses of melt and magmatic fluids that are formed by repeated intrusion of mafic melts from the mantle (Solano et al., 2012; Connolly and Podladchikov, 2013; Christopher et al. 2015). From this perspective, melt and fluid layers are susceptible to destabilisation, and reorganisation of these layers may provide a trigger for eruptive activity in mafic (Tarasewicz et al., 2012; Neave et al., 2013) and large caldera systems (Cashman and Giordano, 2014). Similarly, transcrustal processes can explain apparently anomalous activity in some domebuilding volcanoes (Christopher et al., 2015), whilst also providing a source of deep magma and magmatic fluids. Key is the concept of the meta-stability of transcrustal magmatic systems and destabilisation events that involve either all or part of the melt-bearing region (Fig. 8a,b), with or without contemporaneous eruptive activity (Fig. 8c). 
880 Temporal and spatial variations in the susceptibility of vertically extensive

881 magmatic systems to destabilisation can also explain long-term patterns of eruptive

882 activity at dome-building volcanoes. First we return to the question of mafic

883 eruption triggers, particularly as evidenced by varying intensities of

884 magma mixing in the eruptive products. Mixing has long been used to describe the

885 homogenisation of two melts, as manifested in linear two-element geochemical

886 diagrams. Mixing, however, is increasingly viewed as involving complex interactions

887 between melts and crystal mushes (Blundy et al., 2008; Humphreys et al., 2009;

888 Cashman and Blundy, 2013). From this perspective, the role of mixing as a primary

889 mechanism of eruption triggering is less clear. In fact, mixing may be an effect, as

890 much as a cause, of eruptive activity, particularly if triggered initially by

891 destabilisation of the magmatic system. Destabilisation could occur from the bottom

892 up, with deep level disturbances propagating into the upper crust (e.g., Christopher

893 et al., 2015). Alternatively destabilisation could propagate downward, driven by a

894 downward propagating decompression wave caused by early eruptive activity (e.g.,

895 Tarasewicz et al., 2012). In either case, destabilisation of a complex magmatic

896 system can force interaction among melt lenses and intervening crystal mush zones

897 (e.g., Cashman and Giordano, 2014).

898

899 Another important aspect of dome-building volcanoes in hydrous arc system relates

900 to the evolution and migration of volatiles. Fractionation of deeply sourced arc

901 basalts (Annen et al., 2006) can cause sulphur saturation of more evolved felsic 
902

903

904

905

906

907

908

909

910

911

912

913

914

915

916

917

918

919

920

921

922

923

924

melts in the middle and lower crust (Wallace, 2005). This occurs because, although sulphur is highly soluble in basaltic melts, it is much less soluble in felsic melts (Lesne et al., 2011). As a consequence, $\mathrm{SO}_{2}$ degassing can start deep within the crust, well below levels of shallow magma storage. The same is true of $\mathrm{CO}_{2}$, where strong pressure-dependence may promote $\mathrm{CO}_{2}$ exsolution throughout the crust (e.g., Blundy et al., 2010). Different volatile elements can therefore be fractionated and stored independently at multiple crustal levels during inter-eruptive periods of repose. Separation of volatiles from their parental magmas during these periods of repose can explain both the excess $\mathrm{SO}_{2}$ degassing and decoupling of gas and magma fluxes observed in dome-building volcanoes in the persistent regime. Ascent of magmatic fluids from depth can also explain decoupling of shallow seismicity from eruptive activity (Moran, 1994; Roman et al., 2004; Girona et al., 2014; Hautmann et al., 2014, Christopher et al., 2015). Similarly, deep (20 to $40 \mathrm{~km}$ ), long period earthquakes in arcs can be explained by exsolution and migration of insoluble gases like $\mathrm{CO}_{2}$ (McNutt, 2005; Nichols et al., 2011). Finally, independent rise of magmatic fluids may cause the surface deformation observed at passively degassing volcanoes (Girona et al., 2014), and can help to explain varying timescales of far-field inflation at dome-building volcanoes.

\subsection{Persistent dome-building behaviour}

The persistent regime combines pulsatory phases of effusive eruption and homogeneous magma compositions with sustained, and decoupled, degassing (section 3.1.1), and is typical of 'open' system behaviour (e.g., Chaussard et al., 
925 2013). These observations appear to require a dynamically connected, through-

926 going magmatic system to sustain a persistent regime, especially over long

927 timescales. Large explosive eruptions in these systems involve magma that is more

928 mafic (deeper, more volatile-rich) than that produced during effusive activity.

929 Transitions between persistent shallow-seated effusive behaviour and intermittent

930 deep-seated explosions thus suggest that magmatic systems at these volcanoes are

931 vertically extensive and (transiently) dynamically connected, at least to mid-crustal

932 levels (Fig. 8a). More generally, rapid transport of deep, mafic and volatile-rich

933 magmas is commonly invoked for paroxysmal events at open-system basaltic

934 volcanoes (e.g., Métrich et al., 2010; Sides et al., 2014).

935

936 Eruptive activity at a second group of volcanoes in the persistent regime (section

937 3.1.2) reactivated with major explosive events that followed long periods of inter-

938 eruptive repose. In these volcanoes, the explosively erupted magma is more evolved

939 than subsequent extrusive lavas, which show gradual decreases in $\mathrm{SiO}_{2}$ with time.

940 Progressive variation in the composition of erupted products can be explained by a

941 vertically extensive and connected magmatic system, although a more traditional

942 zoned magma chamber model (e.g., Scott et al., 2013) cannot be excluded on the

943 basis of these characteristics alone. Most important from a volcanic hazards

944 perspective, however, are the compositional homogeneity and paucity of mafic

945 enclaves (Scott et al., 2013; Turner et al., 2013) that characterise activity. This

946 suggests that these persistently active volcanoes have relatively stable magmatic 
systems that are less susceptible to large-scale destabilisation than during inter-

948 eruptive periods of repose.

949

950 The observation that explosive eruptions may be either more or less evolved than

951 magma erupted effusively from the same system provides insight into explosive

952 eruption triggers. 'Top-down' destabilisation is observed in cases of edifice collapse

953 following either a long duration in a state of inter-eruptive repose (Bezymianny,

954 Santiaguito, Mount St. Helens) or sustained effusive activity and dome growth

955 (Lascar). Top-down triggering taps evolved magma from high in the crust. 'Bottom-

956 up' destabilisation, in contrast, explains explosive events that appear to be triggered

957 by the rapid rise of deep-derived magmas (Merapi, Colima, Shiveluch).

958

959 Persistent eruptive regimes require that the magmatic system is 'open', or vertically

960 connected. Under these conditions, eruptive activity may be neither strictly 'top

961 down' nor 'bottom up' but instead reflect the intrinsic instability of complex

962 magmatic systems. One mechanism of instability relates to the behaviour of crystal-

963 melt suspensions, which segregate to form separate layers of melt and/or volatiles.

964 We suggest that these (unstable) layers can reorganise rapidly to trigger abrupt

965 changes in eruption patterns. Layer destabilisation may occur because of external

966 triggers, such as regional tectonics or eruptions of neighbouring volcanoes (e.g.,

967 Walter et al., 2007; De la Cruz-Reyna et al., 2010; Biggs et al., 2016). Alternatively,

968 passive volatile release during a state of repose may cause the pressure distribution

969 sufficiently to cause replenishment of magma from depth (Girona et al., 2015). Such 
mechanisms are not restricted to dome-building volcanoes, and have been observed at basaltic arc systems that are vertically well-connected and exhibit complex feedback mechanisms for magma discharge (e.g., Stromboli; Ripepe et al., 2015).

\subsection{Episodic dome-building behaviour}

Dome-building volcanoes that show episodic behaviour are characterised by diminishing eruption rates with time and correlations between lava extrusion and volatile emission. Both characteristics are indicative of closed system behaviour, which likely reflects the formation and ascent of discrete magma batches. In many of these volcanoes, however, there is evidence for the interaction of different melts (Table 3), which argues against discrete melt batches. In fact, volcanoes in an episodic regime that erupt frequently (e.g., Augustine, Redoubt) erupt a wide range of compositions during any individual eruption. This suggests that small melt batches evolve independently and interact only during eruptions (e.g., Roman et al., 2006). More homogeneous magma compositions produced by volcanoes that erupt less frequently (e.g., Mont Pelée, Unzen), in contrast, suggests that magma mixing may occur prior to, as well as during, eruptive episodes (Browne et al., 2006).

A magmatic model based on the shallow chamber paradigm suggests that if magmas are generated at a constant rate at depth, then the duration a volcano remains in a state of repose will control the volume of magma components (volatiles, melt, and crystal mush) that can accumulate; this time-dependent volume may, in turn, influence the duration a volcano remains in an eruptive state. In contrast, under the 
993

994

995

996

997

998

999

1000

1001

1002

1003

1004

1005

1006

1007

1008

1009

1010

1011

1012 A different situation occurred at Mount St. Helens in 1980, where the initial

1013 explosive eruption was related to edifice collapse, but the prior repose interval was

1014

1015

transcrustal paradigm, variations in frequency and duration of eruptive episodes could reflect patterns of destabilisation within the deeper system. Stability may be controlled by physical properties, such as the size of magmatic systems, or fundamental parameters such as the flux of magma at depth (Caricchi et al., 2014).

\subsection{Large-magnitude explosive eruptions}

The dynamic nature of eruptive activity at dome-building volcanoes suggests that past behaviour is likely to influence stability of the magmatic system, and future patterns of eruptive activity. For example, edifice collapse associated with large magnitude explosions is known to reduce storage pressures (Pinel \& Albino, 2013) and enable the eruption of denser, more mafic magmas, which would otherwise stall at shallow depths (Pinel \& Jaupart, 2000; 2005). Indeed, volcanoes in our dataset where the onset of eruptive activity involved edifice collapse may well have shown different long-term patterns of eruptive activity if the onset of eruptive activity had been effusive. Conversely, where edifice collapse occurred after a long duration in a state of repose ( $\sim$ millenia), persistent activity appears to last for many decades (e.g. Bezymianny, Santiaguito; Fig. 2). Removal of the edifice during these large magnitude events thus appears to destabilise the system (Pinel \& Albino, 2013). only slightly more than a century. In this case, persistent behaviour continued for only six years. It is noteworthy that the volcano reactivated between 2004-2008 
(Fig. 2) after two intervening episodes of inferred recharge from deeper in the system (Moran, 1994; Musumeci et al., 2002). The limited persistent activity of Mount St. Helens compared to Bezymianny and Santiaguito may be simply a result of shorter inter-eruptive repose, which could limit the accumulation of eruptible magma. Alternatively, it may be related to the dacitic composition of magma at

1021 Mount St. Helens, compared to the andesitic magmas of Bezymianny and 1022 Santiaguito.

1023

\section{Conceptualising volcanism in time}

1025

1026 Records of eruptive activity inform our understanding of magmatic processes and 1027 are commonly the basis for forecasts of eruptive activity. Traditionally, volcanism is 1028 conceptualised as a series of discrete eruptions (Siebert et al., 2010) that are 1029 characterised by measureable properties such as magnitude, duration, intensity and 1030 eruptive style (Mercalli, 1907; Newhall and Self, 1982; Pyle, 2000). The intervals 1031 between eruptions are usually referred to as repose periods and at these times the 1032 volcano is commonly interpreted to be in a dormant state. This ontology of volcanic 1033 activity as a point process stems from geological records that comprise a punctuated 1034 series of distinct deposits, and historical records that are biased towards occasional 1035 memorable, and generally explosive, individual events (Szakács and Cañón-Tapia, 1036 2010). 
1038 A different perspective emerges from our analysis of long-term eruptive behaviours

1039 at fifteen well-studied dome-building volcanoes. Instead of identifying discrete

1040 eruptions, we suggest that periods of eruptive activity be classified in the context of

1041 the eruptive history. For example, at two different volcanoes, periods of dome

1042 extrusion may have similar lava volumes, rates of extrusion, and duration, but can

1043 occur in very different situations (e.g., as period of episodic activity or a phase of

1044 lava extrusion in a persistent regime). Including time as a key parameter highlights

1045 the shortcomings of viewing volcanoes as in only either an "eruptive" or "non-

1046 eruptive" state. Critically, this ontology of volcanic activity should influence

1047 interpretation of both volcanic data and inferred magmatic processes.

1048

1049 The evidence for different states of repose provided by our case studies suggests

1050 that lava dome-building volcanoes can be characterised by three, rather than two,

1051 states: (i) a state of dormancy without abnormal geochemical or geophysical signals

1052 (inter-eruptive); (ii) an active state in which magma is erupted; and (iii) a state of

1053 unrest where perturbations in the system at depth cause marked and measurable

1054 departures from a background (dormant) state (intra-eruptive). Historical records

1055 allow volcano classification by one, two or all three of these states. Over geological

1056 timescales, we assume all volcanoes experience periods of dormancy or inter-

1057 eruptive repose periods. Intra-eruptive repose periods can be more difficult to

1058 identify, and present the greatest challenges for volcanic hazard assessment. 
1060

1061

1062

1063

1064

1065

1066

1067

1068

1069

1070

1071

1072

1073

1074

1075

1076

1077

1078

1079

1080

1081

Inter-eruptive repose occurs at volcanoes that show episodic behaviour, meaning that they conform more closely to the traditional interpretation of volcanism as a sequence of discrete eruptions. The duration of inter-eruptive repose can vary from many years (e.g., Augustine, Redoubt) to centuries (e.g., Mount Unzen), but in all cases the volcano is deemed to be in a dormant state between eruptive periods. Volcanoes classified as dormant can move into the unrest state with increases in geophysical (e.g., seismicity, and deformation) and fumarolic activity. For example, prior to 1992, Soufrière Hills Volcano had been in a dormant state for over 350 years, but had moved into a state of unrest in 1896-97, 1933-37 and 1966-67, as evidenced by elevated fumarolic activity and intermittent seismic crises (Shepherd et al., 1971; Odbert et al., 2014b). Similar seismic crises were also observed throughout the $20^{\text {th }}$ century at Mt Unzen prior to eruption onset in 1991 (Japan Meteorological Agency, 1996).

Intra-eruptive repose is observed at volcanoes in a persistent regime where intervals between pulses of eruptive activity can last for months to years or even decades, especially following major explosive events (e.g., Bezymianny, Colima, Lascar, Santiaguito). At these volcanoes, however, periods of repose are characterised by sustained degassing, intermittent seismicity and ash venting, all of which indicate magmatic unrest that is not consistent with dormancy. Importantly, unrest under these conditions does not imply imminent eruptive activity, as observed in the example of Kudryavy where a persistent state of high temperature 
1082

1083

1084

1085

1086

1087

1088

1089

1090

1091

1092

1093

1094

1095

1096

1097 The conceptualisation of eruptions as discrete events has been, and still is,

1098

1099

1100

1101

1102

1103

1104

fumarolic degassing and phreatic activity is inferred since its last magmatic eruption in 1883 (Fischer et al., 1998; Korzhinsky et al., 2002).

By characterising exchangeable traits of volcanic behaviour, we demonstrate that the case histories in this review challenge the depiction of volcanism as a point process in time, and raise questions about what it means to say that a volcano is dormant and how to view periods of non-eruptive volcanic unrest. Importantly, several of our case study volcanoes show unrest signals that are greatly elevated after eruptive activity, in comparison to unrest signals when a volcano is in a period of longer dormancy (e.g., Merapi, Lascar, Bezymianny). For this reason, we suggest that the state of unrest be used to classify volcanic activity, with the caveat that it is important to recognise when the distinction between unrest and dormancy is determined by a change in detection thresholds and not by true changes in the state of a magmatic system.

fundamental to volcano classification, volcano databases, data selection in probabilistic forecasts and the interpretation of magmatic processes. The GVP database (Siebert et al., 2010) is the only comprehensive global compilation of active volcanoes, and is widely used to characterise volcanism, inform interpretations of volcanic processes and provide evidence for eruptive forecasts.

The catalogue is predicated, however, on viewing volcanism as an alternation of two different events, repose period and eruption. The GVP further defines repose as any 
1105

1106

1107

1108

1109

1110

1111

1112

1113

1114

1115

1116

1117

1118

1119

1120

1121

1122

1123

1124

1125

1126

1127

cessation in eruptive activity that exceeds 3 months. This definition works well for some of our case studies (e.g., Augustine, Redoubt), but is problematic for volcanoes showing prolonged intermittent activity (e.g., Bezymianny, Mount St. Helens, Merapi, Soufrière Hills Volcano). More critically, the GVP database structure does not record information that is useful for both characterising and interpreting states of eruption and unrest.

\section{Information exchangeability in forecasting volcanic activity}

In recent decades probabilistic methods have become established as the principal approach to forecasting volcanic activity. Importantly, they can capture both aleatory and epistemic uncertainties and include multiple strands of evidence and different kinds of data (e.g., Newhall and Hoblitt, 2002; Aspinall et al., 2003; Marzocchi et al., 2004; Sparks and Aspinall, 2004; Neri et al., 2008; Sobradelo et al., 2013; Aspinall and Woo, 2014; Hincks et al., 2014; Sobradelo and Martí, 2015).

Probabilistic approaches, however, have highlighted specific challenges associated with eruptive forecasts at dome-building volcanoes. The most acute problem relates to a lack of data, especially at volcanoes with infrequent eruptive activity in episodic regimes. The issue of sparse data, however, can also manifest at volcanoes in a persistent regime, when forecasting a long period of dormancy. Consequently, an important question in volcanology is whether observations from a number of wellstudied volcanoes can be used to reduce uncertainty associated with a lack of data at an individual volcano. This is especially pertinent with the development of global 

data collection (e.g., Biggs et al., 2014; Carn et al., 2016).

1130

1131

1132

1133

1134

1135

1136

1137

1138

1139

1140

1141

1142

1143

1144

1145 comparisons with other volcanoes enter into these discussions, at least informally.

1146 In many volcano emergencies, for example, such assessments are ad hoc and

1147 executed largely through unstructured discussion within a volcano observatory

1148 team. These efforts can be improved by formalised methods for pooling expert

1149 judgements, as illustrated by hazard assessments for Soufrière Hills Volcano (Wadge

1150 and Aspinall, 2014). Importantly, the experience of an expert in previous volcanic 
1151

1152 informal approach, where the basis for assessment may be anecdotal and biased

1153 towards previously witnessed discrete events. Moreover, even the most experienced

1154 volcanologist is unlikely to have witnessed more than a handful of eruptive events,

1155 so these comparisons warrant a more rigorous approach to identifying appropriate

1156 analogue volcanoes and to what extent comparisons are justified.

1157

1158 Broad classifications for volcano 'type' based on characteristics such as morphology

1159 (Rittmann, 1962; Siebert et al., 2010) or eruptive style (e.g., Hawaiian, Strombolian,

1160 Peléean, Vulcanian and Plinian; Bullard, 1962) provide a natural framework for

1161 assumptions of exchangeability. However, as the analysis in this review has

1162 outlined, the historical records of dome-building volcanoes are only partially

1163 exchangeable. Thus, whilst exchangeability may be assumed based on volcano 'type'

1164 (e.g., lava-dome building), the limitations and sources of aleatory uncertainty of

1165 probabilistic forecasts that arise from this assumption must be addressed by

1166 identifying both the underlying conceptual model and the common process that

1167 together form the basis for exchangeability. It is equally important to recognise key

1168 differences when applying exchangeability. This is evident in a cladistics analysis of

1169 Japanese arc volcanoes (Hone et al., 2007) that identified three broad volcano types

1170 grouped by composition, eruptive products and morphological characteristics.

1171 Differences are also identified in a study of magnitude-frequency relations that

1172 treats separately closed- and open-vent stratovolcanoes (Whelley et al., 2015). 


\subsection{Volcanic unrest}

1175 The concept of exchangeability can be used to interpret volcanic unrest, which is an

1176 almost a ubiquitous precursor to volcanic activity. Signs of unrest are typically

1177 monitored using geodetic, geophysical and geochemical surveys (e.g., Swanson et al.,

1178 1983; Sparks, 2003; Sandri et al., 2004; Jaquet et al., 2006; Chouet and Matoza,

1179 2013). Critically, these monitoring data are used to infer magmatic processes (e.g.,

1180 Voight, 1988; Kilburn, 2003; Smith et al., 2007; Lavallée et al., 2008), an approach

1181 that requires implicit, if not explicit, comparisons with unrest from previous activity.

1182

1183 The simplest approach to comparing volcanic unrest among volcanoes is to consider

1184 all signals of unrest as weakly exchangeable, with variations in the duration, pattern

1185 and occurrence the result of aleatory uncertainty, reflecting the natural variability of

1186 volcanic systems. A stronger assumption of exchangeability compares signs of

1187 unrest between volcanoes of a specific type (e.g., Phillipson et al., 2013), with the

1188 underlying assumption that different types of volcanoes should behave in similar

1189 ways. Our work shows, however, that even particular volcano 'types' can vary

1190 greatly in behaviour. In particular, we have shown that intra-repose unrest of a

1191 volcano in a persistent regime may reflect a very different state of activity than

1192 inter-repose unrest in the episodic regime, which may herald the onset of explosive

1193 activity. In this way, our categorization of eruptive activity at dome-building

1194 volcanoes as episodic (closed-system) or persistent (open-system) could help to

1195 further refine classifications of unrest, particularly with regard to the problem of

1196 distinguishing between non-eruptive unrest and unrest related to reawakening of a 
1197 volcano in repose (e.g., Phillipson et al., 2013). Furthermore, by attempting to

1198 understand differences in episodic and persistent behaviour in terms of magmatic

1199 processes, this provides an opportunity to interpret patterns of volcanic unrest in

1200 terms of these magmatic processes, rather than purely the outcome of eruptive

1201 activity (e.g., Hincks et al., 2014).

1202

\section{8. Conclusions}

1204

1205 We have shown that dome-building volcanoes show two fundamentally different

1206 patterns of eruptive behaviours that we term episodic and persistent. Episodic

1207 behaviour is characterised by discrete episodes comprising an explosive onset

1208 followed by effusion and dome formation. In this regime, explosively erupted

1209 magma may have more evolved compositions than later-erupted lava. Excess gas

1210 emissions may be observed during explosive activity, but $\mathrm{SO}_{2}$ fluxes are correlated

1211 with the eruption of lava and diminish to negligible levels following the end of each

1212 eruptive episode. Persistent behaviour, in contrast, is characterised by frequent

1213 ( yearly) phases of eruptive activity and sustained gas fluxes during periods of

1214 intra-eruptive repose. Erupted material is often compositionally homogeneous,

1215 except during explosive (paroxysmal) eruptions, which often involve deep, more

1216 primitive, magma compositions. Alternatively, at volcanoes that have not erupted

1217 for a long time ( millenia), large explosive Plinian eruptions can be followed by

1218 persistent behaviour where lava compositions become less evolved with time.

1219 Importantly, all volcanic activity is episodic if viewed over sufficiently long times. 
1221 We explain the variety of episodic and persistent behaviour through the lens of

1222 vertically extensive magmatic systems, where the extent of connectivity within the

1223 system dictates episodic or persistent behaviour (e.g., Christopher et al., 2015).

1224 Importantly, open-system behaviour involves transient, dynamically triggered

1225 magma transfer from depth but continuous gas transfer through the system.

1226 Episodic behaviour, in contrast, records eruption and gas loss from a magma batch

1227 that is quickly isolated from deeper (mid-crustal) reservoir. An interesting question

1228 relates to the importance of volatiles and volatile-rich melts in determining the

1229 stability of a magmatic system, particularly transitions between episodic and

1230 persistent regimes, and eruption triggering in episodic regimes (e.g., Borisova et al.,

1231 2014; Christopher at al., 2015; Girona et al., 2015).

1232

1233 From a hazard forecasting perspective, our 15 case studies show that dome-building

1234 volcanic activity cannot be characterised by a point process. This observation

1235 highlights a key ontological issue for volcanology. Discrete eruptive events can

1236 appear similar in nature in both an episodic and persistent regime, but are

1237 associated with different states of repose and long-term behaviour. Therefore, when

1238 analysing volcanic data, and interpreting magmatic processes, it is important to

1239 characterise eruptive activity in the context of the longer-term behaviour of a

1240 volcanic system. We have shown that gas data, in particular, may help to

1241 discriminate between inter-and intra-eruptive repose. Also important are patterns 
1242 of seismicity, which provide information on the depth and volume of magma storage

1243 (e.g., White and McCausland, 2016).

1244

1245 Also important for hazard forecasting is developing a method to determine how

1246 monitoring data from well-observed volcanoes can be used to inform

1247 interpretations of monitoring data from periods of unrest at less-studied volcanoes.

1248 Such an approach is feasible, but requires an understanding of the extent to which

1249 the monitoring data can be considered exchangeable. We suggest that

1250 exchangeability can be formalised by assessing temporal patterns in volcanic

1251 phenomena (especially relative patterns of eruption, degassing and repose), even if

1252 the datasets have different spatial and temporal data. From a theoretical standpoint,

1253 linking assumptions of exchangeability (e.g., episodic vs. persistent) to conceptual

1254 models of volcanic systems (e.g., closed vs. open) provides a mechanism to interpret

1255 monitoring data using a framework of magmatic processes.

1256

1257 Importantly, the approach employed in this review cannot be used to identify

1258 unique magmatic processes at individual volcanoes, and in that sense cannot replace

1259 'in-depth' studies of individual volcanic systems. However, it provides a conceptual

1260 framework for interpreting common processes at dome-building volcanoes. From a

1261 broader perspective, our work demonstrates the value of constructing a hierarchical

1262 framework for volcanic activity based on exchangeable behaviours. We suggest that

1263 this approach could be extended to volcanoes with other types of characteristic

1264 activity, and thus provides a holistic approach to analysing global volcanic records. 
Acknowledgements

1267 Many thanks to Prof. Jonty Rougier in the School of Mathematics, University of

1268 Bristol, who provided advice on the definition and application of exchangeability,

\section{References:}

Almeev, R. R., Holtz, F., Ariskin, A. A., Kimura, J-I., 2013. Storage conditions of Bezymianny Volcano parental magmas: results of phase equilibria experiments at 100 and $700 \mathrm{MPa}$. Contributions to Mineralogy and Petrology 166, 1389-1414.

1287 Anderson, S., Fink, J., 1990. The Development and Distribution of Surface Textures at the Mount St. Helens Dome. In: Fink, J. H. (Ed.), Lava Flows and Domes. Vol. 2 of IAVCEI Proceedings in Volcanology. Springer Berlin Heidelberg, pp. 25-46.

Andreastuti, S., Alloway, B., Smith, I., 2000. A detailed tephrostratigraphic framework at Merapi Volcano, Central Java, Indonesia: implications for eruption predictions and hazard assessment. Journal of Volcanology and Geothermal Research 100, 51-67.

1294 Andres, R., Rose, W., Stoiber, R., Williams, S., Matías, O., Morales, R., 1993. A summary of sulfur dioxide emission rate measurements from Guatemalan volcanoes. Bulletin of Volcanology 55, 379-388.

1297 Andres, R., Rose, W., Kyle, P., DeSilva, S., Francis, P., Gardeweg, M., Roa, H. M., 1991. 1298 Excessive sulfur dioxide emissions from Chilean volcanoes. Journal of Volcanology 1299 and Geothermal Research 46, 323-329.

1300 Annen, C., Blundy, J. D., Sparks, R. S. J, 2006. The Genesis of Intermediate and Silicic Magmas in Deep Crustal Hot Zones. Journal of Petrology 47, 505-539. 
1304

1305

1306

1307

1308

1309

1310

1311

1312

1313

1314

1315

1316

1317

1318

1319

1320

1321

1322

1323

1324

1325

1326

1327

1328

1329

1330

1331

1332

1333

1334

1335

1336

1337

1338

1339

1340

1341

1342 eruptive period, inferred from remote spectroscopic measurements of $\mathrm{SO}_{2}$ emissions. Journal of Volcanology and Geothermal Research 176, 151-162.

Asch, G., Wylegalla, K., Hellweg, M., Seidl, D., Rademacher, H., 1996. Observations of rapid-fire event tremor at Lascar volcano, Chile. Annals of Geophysics 39.

Aspinall, W., 2010. A route to more tractable expert advice. Nature 463, 294-295.

Aspinall, W., Woo, G., 2014. Santorini unrest 2011-2012: an immediate Bayesian belief network analysis of eruption scenario probabilities for urgent decision support under uncertainty. Journal of Applied Volcanology 3.

Aspinall, W. P., Cooke, R. M., 2013. Expert elicitation and judgement. In: Risk and Uncertainty Assessment for Natural Hazards. Cambridge University Press, Ch. 4, pp. 64-99.

Aspinall, W., Woo, G., Voight, B., Baxter, P., 2003. Evidence-based volcanology: application to eruption crises. Journal of Volcanology and Geothermal Research 128, 273-285.

Athanasopoulos, P., 1997. The origin and ascent history of the 1996 dacitic dome, Volcán Popocatépetl, Mexico. B.Sc. thesis, University of Manitoba, Winnipeg.

Atlas, Z. D., Dixon, J. E., Sen, G., Finny, M., Martin-Del Pozzo, A. L., 2006. Melt inclusions from Volcán Popocatépetl and Volcán de Colima, Mexico: Melt evolution due to vapor-saturated crystallization during ascent. Journal of Volcanology and Geothermal Research 153, 221-240.

Auker, M., Sparks, R. S., Siebert, L., Crosweller, H. S., Ewert, J., 2013. A statistical analysis of the global historical volcanic fatalities record. Journal of Applied Volcanology 2.

Barclay, J., Herd, R. A., Edwards, B. R., Christopher, T., Kiddle, E. J., Plail, M., Donovan, A., 2010. Caught in the act: Implications for the increasing abundance of mafic enclaves during the recent eruptive episodes of the Soufrière Hills Volcano, Montserrat. Geophysical Research Letters 37.

Barclay, J., Rutherford, M. J., Carroll, M. R., Murphy, M. D., Devine, J. D., Gardner, J., Sparks, R. S. J., 1998. Experimental phase equilibria constraints on pre-eruptive storage conditions of the Soufrière Hills magma. Geophysical Research Letters 25, 3437-3440.

Barker, S. E., Malone, S. D., 1991. Magmatic system geometry at Mount St. Helens modeled from the stress field associated with posteruptive earthquakes. Journal of Geophysical Research: Solid Earth 96, 11883-11894.

Barmin, A., Melnik, O., Sparks, R., 2002. Periodic behavior in lava dome eruptions. Earth and Planetary Science Letters 199, 173-184.

Beauducel, F., Cornet, F. H., 1999. Collection and three-dimensional modeling of GPS and tilt data at Merapi volcano, Java. Journal of Geophysical Research: Solid Earth $104,725-736$. 
1343

1344

1345

1346

1347

1348

1349

1350

1351

1352

1353

1354

1355

1356

1357

1358

1359

1360

1361

1362

1363

1364

1365

1366

1367

1368

1369

1370

1371

1372

1373

1374

1375

1376

1377

1378

1379

1380

1381

1382

Bebbington, M., 2014. Long-term forecasting of volcanic explosivity. Geophysical Journal International 197, 1500-1515.

Belousov, A., 1996. Deposits of the 30 March 1956 directed blast at Bezymianny volcano, Kamchatka, Russia. Bulletin of Volcanology 57, 649-662.

Belousov, A. B., 1995. The Shiveluch volcanic eruption of 12 November 1964explosive eruption provoked by failure of the edifice. Journal of Volcanology and Geothermal Research 66, 357-365.

Belousov, A., Voight, B., Belousova, M., 2007. Directed blasts and blast-generated pyroclastic density currents: a comparison of the Bezymianny 1956, Mount St Helens 1980, and Soufrière Hills, Montserrat 1997 eruptions and deposits. Bulletin of Volcanology 69, 701- 740.

Belousov, A., Voight, B., Belousova, M., Petukhin, A., 2002. Pyroclastic surges and flows from the 8-10 May 1997 explosive eruption of Bezymianny volcano, Kamchatka, Russia. Bulletin of Volcanology 64, 455-471.

Bernardo, J. M. (1996). The concept of exchangeability and its applications. Far East Journal of Mathematical Sciences 4, 111-121.

Best, N., Ashby, D., Dunstan, F., Foreman, D., McIntosh, N., 2013. A Bayesian approach to complex clinical diagnoses: a case-study in child abuse. Journal of the Royal Statistical Society: Series A (Statistics in Society) 176, 53-96.

Biggs, J., Robertson, E., Cashman, K., 2016, The lateral extent of volcanic interactions during unrest and eruption. Nature Geoscience 9, 308-311.

Biggs, J., Ebmeier, S. K., Aspinall, W. P., Lu, Z., Pritchard, M. E., Sparks, R. S. J., Mather, T. A., 2014. Global link between deformation and volcanic eruption quantified by satellite imagery. Nature Communications 5.

Blundy, J., Cashman, K., Rust, A., Witham, F., 2010. A case for $\mathrm{CO}_{2}$-rich arc magmas. Earth and Planetary Science Letters 290, 289-301.

Blundy, J., Cashman, K. V., Berlo, K., 2008. Evolving Magma Storage Conditions Beneath Mount St. Helens Inferred from Chemical Variations in Melt Inclusions from the 1980-1986 and Current (2004-2006) Eruptions. In: Sherrod, D. R., Scott, W. E., Stauffer, P. H. (Eds.), A Volcano Rekindled: The Renewed Eruption of Mount St. Helens, 2004-2006. U.S. Geological Survey Professional Paper 1750, Ch. 33, pp. 755790.

Blundy, J., Cashman, K., 2001. Ascent-driven crystallisation of dacite magmas at Mount St Helens, 1980-1986. Contributions to Mineralogy and Petrology 140, 631650.

Bogoyavlenskaya, G., Braitseva, O., Melekestsev, I., Kiriyanov, V., Miller, C. D., 1985. Catastrophic eruptions of the directed-blast type at Mount St. Helens, Bezymianny and Shiveluch volcanoes. Journal of Geodynamics 3, 189-218.

Borgia, A., Aubert, M., Merle, O., van Wyk de Vries, B., 2010. What is a volcano? Geological Society of America Special Papers 470, 1-9. 
1383

1384

1385

1386

1387

1388

1389

1390

1391

1392

1393

1394

1395

1396

1397

1398

1399

1400

1401

1402

1403

1404

1405

1406

1407

1408

1409

1410

1411

1412

1413

1414

1415

1416

1417

1418

1419

1420

1421

Borisova, A Y., Toutain, J-P, Dubessy, J., Pallister, J., Zwick, A., Salvi, S., 2014. $\mathrm{H}_{2} \mathrm{O}-\mathrm{CO}_{2}$ $S$ fluid triggering the 1991 Mount Pinatubo climactic eruption (Philippines). Bulletin of Volcanology 76.

Bullard, F. M., 1962. Volcanoes in History, in Theory, in Eruption. Austin, University of Texas Press.

Brennan, C., 2007. The far side of the sky. Dankat Publishing.

Browne, B. L., Eichelberger, J. C., Patino, L. C., Vogel, T. A., Dehn, J., Uto, K., Hoshizumi, H., 2006. Generation of Porphyritic and Equigranular Mafic Enclaves During Magma Recharge Events at Unzen Volcano, Japan. Journal of Petrology 47, 301-328.

Budi-Santoso, A., Lesage, P., Dwiyono, S., Sumarti, S., Subandriyo, Surono, Jousset, P., Metaxian, J-P., 2013. Analysis of the seismic activity associated with the 2010 eruption of Merapi Volcano, Java. Journal of Volcanology and Geothermal Research 261, 153-170.

Bull, K. F., Buurman, H., 2013. An overview of the 2009 eruption of Redoubt Volcano, Alaska. Journal of Volcanology and Geothermal Research 259, 2-15.

Cabral-Cano, E., Correa-Mora, F., Meertens, C., 2008. Deformation of Popocatépetl volcano using GPS: Regional geodynamic context and constraints on its magma chamber. Journal of Volcanology and Geothermal Research 170, 24-34.

Calder, E. S., Lavallée, Y., Kendrick, J. E., Bernstein, M., 2015. Chapter 18-Lava Dome Eruptions . In: Sigurdsson, H. et al., (Eds.), The Encyclopedia of Volcanoes, 2nd Edition. Academic Press, pp. 343-362.

Cañón-Tapia, E., Walker, G. P. L., 2004. Global aspects of volcanism: the perspectives of "plate tectonics" and "volcanic systems". Earth-Science Reviews 66, 163-182.

Caricchi, L., Annen, C., Blundy, J., Simpson, G., Pinel, V., 2014. Frequency and magnitude of volcanic eruptions controlled by magma injection and buoyancy. Nature Geoscience 7, 126- 130.

Carn, S. A., Clarisse, L., Prata, A. J., 2016. Multi-decadal satellite measurements of global volcanic degassing. Journal of Volcanology and Geothermal Research 311, 99134.

Carn, S. A., Krotkov, N. A., Yang, K., Krueger, A. J., 2013. Measuring global volcanic degassing with the Ozone Monitoring Instrument (OMI). Geological Society, London, Special Publications 380.

Carn, S. A., Prata, F. J., 2010. Satellite-based constraints on explosive $\mathrm{SO}_{2}$ release from Soufrière Hills Volcano, Montserrat. Geophysical Research Letters 37 (19).

Casadevall, T., Doukas, M., Neal, C., McGimsey, R., Gardner, C., 1994. Emission rates of sulfur dioxide and carbon dioxide from Redoubt Volcano, Alaska, during the 1989 1990 eruptions. Journal of Volcanology and Geothermal Research 62, 519-530.

Casadevall, T. J., Rose, W. I., Fuller, W. H., Hunt, W. H., Hart, M. A., Moyers, J. L., Woods, D. C., Chuan, R. L., Friend, J. P., 1984. Sulfur dioxide and particles in quiescent 
volcanic plumes from Poás, Arenal, and Colima Volcanos, Costa Rica and Mexico. Journal of Geophysical Research: Atmospheres 89, 9633-9641.

Casertano, L., 1963. Catalogue of the active volcanoes of the world; Part XV, Chilean continent. IAVCEI 55pp.

Cashman, K., Biggs, J., 2014. Common processes at unique volcanoes - a volcanological conundrum. Frontiers in Earth Science 2.

Cashman, K. V., Giordano, G., 2014. Calderas and magma reservoirs. Journal of Volcanology and Geothermal Research 288, 28-45.

Cashman, K., Blundy, J., 2013. Petrological cannibalism: the chemical and textural consequences of incremental magma body growth. Contributions to Mineralogy and Petrology 166, 703-729.

Cashman, K. V., Sparks, R. S. J., 2013. How volcanoes work: A 25 year perspective. Geological Society of America Bulletin.

Cashman, K. V., Thornber, C. R., Pallister, J. S., 2008. From Dome to Dust: Shallow Crystallization and Fragmentation of Conduit Magma During the 2004-2006 Dome Extrusion of Mount St. Helens, Washington. In: Sherrod, D. R., Scott, W. E., Stauffer, P. H. (Eds.), A Volcano Rekindled: The Renewed Eruption of Mount St. Helens, 20042006. U.S. Geological Survey Professional Paper 1750, Ch. 19, pp. 387-414.

Cashman, K., McConnell, S., 2005. Multiple levels of magma storage during the 1980 summer eruptions of Mount St. Helens, WA. Bulletin of Volcanology 68, 57-75.

Cashman, K. V., 1992. Groundmass crystallization of Mount St. Helens dacite, 19801986: a tool for interpreting shallow magmatic processes. Contributions to Mineralogy and Petrology 109, 431-449.

Cervelli, P. F., Fournier, T. J., Freymueller, J. T., Power, J. A., Lisowski, M., Pauk, B. A., 2010. Geodetic Constraints on Magma Movement and Withdrawl During the 2006 Eruption of Augustine Volcano. In: Power, J. A., Coombs, M. L., Freymueller, J. T. (Eds.), The 2006 Eruption of Augustine Volcano, Alaska. U.S. Geological Survey Professional Paper 1769, Ch. 17, pp. 427-452.

Chaussard, E., Amelung, F., Aoki, Y., 2013. Characterization of open and closed volcanic systems in Indonesia and Mexico using InSAR time series. Journal of Geophysical Research: Solid Earth 118, 3957-3969.

Chouet, B. A., 1996. Long-period volcano seismicity: its source and use in eruption forecasting. Nature 380, 309-316.

Chouet, B. A., Matoza, R. S., 2013. A multi-decadal view of seismic methods for detecting precursors of magma movement and eruption. Journal of Volcanology and Geothermal Research 252, 108-175.

Christopher, T., Blundy, J., Cashman, K., Cole, P., Edmonds, M., Smith, P., R.S.J, S., Stinton, A., 2015. Crustal-scale degassing due to magma system destabilisation and magma-gas decoupling at Soufrière Hills Volcano, Montserrat. Geochemistry, Geophysics, Geosystems 16, 2797-2811. 
Christopher, T. E., Humphreys, M. C. S., Barclay, J., Genareau, K., De Angelis, S. M. H., Plail, M., Donovan, A., 2014. Petrological and geochemical variation during the Soufrière Hills eruption, 1995 to 2010. Geological Society, London, Memoirs 39, 317342.

Christopher, T., Edmonds, M., Humphreys, M., Herd, R., 2010. Volcanic gas emissions from Soufrière Hills Volcano, Montserrat 1995-2009, with implications for mafic magma supply and degassing. Geophysical Research Letters 37.

Claiborne, L. L., Miller, C. F., Flanagan, D. M., Clynne, M. A., Wooden, J. L., 2010. Zircon reveals protracted magma storage and recycling beneath Mount St. Helens. Geology 38, 1011- 1014.

Cole, P. D., Smith, P., Komorowski, J-C., Alfano, F., Bonadonna, C., Stinton, A., Christopher, T., Odbert, H. M., Loughlin, S., 2014. Ash venting occurring both prior to and during lava extrusion at Soufrière Hills Volcano, Montserrat, from 2005 to 2010. Geological Society, London, Memoirs 39, 71-92.

Coles, S. G., Sparks, R. S. J., 2006. Extreme value methods for modelling historical series of large volcanic magnitudes. In: Mader, H. M., Coles, S. G., Connor, C. B., Connor, L. J. (Eds.), Statistics in Volcanology. Vol. 1 of Special Publications of IAVCEI. Geological Society, London, pp. 47-56.

Connolly, J., Podladchikov, Y., 2013. A Hydromechanical Model for Lower Crustal Fluid Flow. In: Metasomatism and the Chemical Transformation of Rock. Lecture Notes in Earth System Sciences. Springer Berlin Heidelberg, pp. 599-658.

Coombs, M. L., Sisson, T. W., Bleick, H. A., Henton, S. M., Nye, C. J., Payne, A. L., Cameron, C. E., Larsen, J. F., Wallace, K. L., Bull, K. F., 2013. Andesites of the 2009 eruption of Redoubt Volcano, Alaska. Journal of Volcanology and Geothermal Research 259, 349-372.

Coombs, M. L., Bull, K. F., Vallance, J. W., Schneider, D. J., Thoms, E. E., Wessels, R. L., McGimsey, R. G., 2010. Timing, Distribution, and Volume of Proximal Products of the 2006 Eruption of Augustine Volcano. In: Power, J. A., Coombs, M. L., Freymueller, J. T. (Eds.), The 2006 Eruption of Augustine Volcano, Alaska. U.S. Geological Survey Professional Paper 1769, Ch. 8, pp. 145-186.

Cooper, K. M., Reid, M. R., 2008. Uranium-series Crystal Ages. Reviews in Mineralogy and Geochemistry 69, 479-544.

Costa, F., Andreastuti, S., de Maisonneuve, C. B., Pallister, J. S., 2013. Petrological insights into the storage conditions and magmatic processes that yielded the centennial 2010 Merapi explosive eruption. Journal of Volcanology and Geothermal Research 261, 209-235.

Couch, S., Sparks, R., Carroll, M., 2001. Mineral disequilibrium in lavas explained by convective self-mixing in open magma chambers. Nature 411, 1037-1039.

Crummy, J. M., Savov, I. P., Navarro-Ochoa, C., Morgan, D. J., Wilson, M., 2014. High-K Mafic Plinian Eruptions of Volcán de Colima, Mexico. Journal of Petrology 55, 21552192. 
1503

1504

1505

1506

1507

1508

1509

1510

1511

1512

1513

1514

1515

1516

1517

1518

1519

1520

1521

1522

1523

1524

1525

1526

1527

1528

1529

1530

1531

1532

1533

1534

1535

1536

1537

1538

1539

1540

1541

1542
De la Cruz-Reyna, S., Tárraga, M., Ortiz, R., Martínez-Bringas, A., 2010. Tectonic earthquakes triggering volcanic seismicity and eruptions. Case studies at Tungurahua and Popocatépetl volcanoes. Journal of Volcanology and Geothermal Research 193, 37-48.

Delgado-Granados, H., González, L. C., Sánchez, N. P., 2001. Sulfur dioxide emissions from Popocatépetl volcano (Mexico): case study of a high-emission rate, passively degassing erupting volcano. Journal of Volcanology and Geothermal Research 108, 107-120.

Deligne, N. I., Coles, S. G., Sparks, R. S. J., 2010. Recurrence rates of large explosive volcanic eruptions. Journal of Geophysical Research: Solid Earth 115.

Deruelle, B., 1985. Le Volcan Lascar: Geologie et Petrologie. IV Congreso Geologico Chileno, Agosto 1985.

DeShon, H. R., Thurber, C. H., Rowe, C., 2007. High-precision earthquake location and threedimensional $\mathrm{P}$ wave velocity determination at Redoubt Volcano, Alaska. Journal of Geophysical Research: Solid Earth 112.

Diefenbach, A. K., Bull, K. F., Wessels, R. L., McGimsey, R. G., 2013. Photogrammetric monitoring of lava dome growth during the 2009 eruption of Redoubt Volcano. Journal of Volcanology and Geothermal Research 259, 308-316.

Dirksen, O., Humphreys, M., Pletchov, P., Melnik, O., Demyanchuk, Y., Sparks, R., Mahony, S., 2006. The 2001-2004 dome-forming eruption of Shiveluch volcano, Kamchatka: Observation, petrological investigation and numerical modelling. Journal of Volcanology and Geothermal Research 155, 201-226.

Divoux, T., Bertin, E., Vidal, V., Géminar, J.C., 2009. Intermittent outgassing through a non-Newtonian fluid. Physical Review E 79.

Dosseto, A., Turner, S. P., Sandiford, M., Davidson, J., 2008. Uranium-series isotope and thermal constraints on the rate and depth of silicic magma genesis. Geological Society, London, Special Publications 304, 169-181.

Doukas, M., 1995. A compilation of sulfur dioxide and carbon dioxide emission-rate data from Cook Inlet volcanoes (Redoubt, Spurr, Iliamna, and Augustine), Alaska during the period from 1990 to 1994. Tech. rep., U.S. Geological Survey Open-File Report OF 95-0055, 15 pp.

Ebmeier, S., Biggs, J., Mather, T., Elliott, J., Wadge, G., Amelung, F., 2012. Measuring large topographic change with InSAR: Lava thicknesses, extrusion rate and subsidence rate at Santiaguito volcano, Guatemala. Earth and Planetary Science Letters 335-336, 216-225.

Edmonds, M., Humphreys, M. C. S., Hauri, E. H., Herd, R. A., Wadge, G., Rawson, H., Ledden, R., Plail, M., Barclay, J., Aiuppa, A., Christopher, T. E., Giudice, G., Guida, R., 2014. Chapter 16: Pre-eruptive vapour and its role in controlling eruption style and longevity at Soufrière Hills Volcano. Geological Society, London, Memoirs 39, 291315. 
Edmonds, M., Aiuppa, A., Humphreys, M., Moretti, R., Giudice, G., Martin, R. S., Herd, R. A., Christopher, T., 2010. Excess volatiles supplied by mingling of mafic magma at an andesite arc volcano. Geochemistry, Geophysics, Geosystems 11.

Edmonds, M., Herd, R., Galle, B., Oppenheimer, C., 2003. Automated, high timeresolution measurements of $\mathrm{SO}_{2}$ flux at Soufrière Hills Volcano, Montserrat. Bulletin of Volcanology 65, 578-586.

Elsworth, D., Mattioli, G., Taron, J., Voight, B., Herd, R., 2008. Implications of Magma Transfer Between Multiple Reservoirs on Eruption Cycling. Science 322, 246-248.

Engberg, E., 2009. $\mathrm{SO}_{2}$ Emissions at Volcan de Colima, 2003-2007. Master's Thesis, Michigan Technological University.

Fichaut, M., Marcelot, G., Clocchiatti, R., 1989a. Magmatology of Mt. Pelée (Martinique, F.W.I.). II: petrology of gabbroic and dioritic cumulates. Journal of Volcanology and Geothermal Research 38, 171-187.

Fichaut, M., Maury, R., Traineau, H., Westercamp, D., Joron, J., Gourgaud, A., Coulon, C., 1989b. Magmatology of Mt. Pelée (Martinique, F.W.I.). III: Fractional crystallization versus magma mixing. Journal of Volcanology and Geothermal Research 38, 189-213.

Fischer, T. P., Giggenbach, W. F., Sano, Y., Williams, S. N., 1998. Fluxes and sources of volatiles discharged from Kudryavy, a subduction zone volcano, Kurile Islands. Earth and Planetary Science Letters 160, 81-96.

Galle, B., Oppenheimer, C., Geyer, A., McGonigle, A. J., Edmonds, M., Horrocks, L., 2003. A miniaturised ultraviolet spectrometer for remote sensing of $\mathrm{SO}_{2}$ fluxes: a new tool for volcano surveillance. Journal of Volcanology and Geothermal Research $119,241-254$.

Gardeweg, M. C., Medina, E., 1994. La erupcion subpliniana del 19-20 de Abril de 1993 del Volcan Lascar, N de Chile. Actas $7^{\text {th }}$ Congreso Geologico Chileno, Santiago, 1:299-304.

Gelman, A., Carlin, J. B., Stern, H. S., Rubin, D. B., 2004. Bayesian Data Analysis. 2nd Edition. Chapman \& Hall/CRC, Boca Raton.

Gerlach, T. M., McGee, K. A., Doukas, M. P., 2008. Use of Digital Aerophotogrammetry to Determine Rates of Lava Dome Growth, Mount St. Helens, Washington, 20042005. In: Sherrod, D. R., Scott, W. E., Stauffer, P. H. (Eds.), A Volcano Rekindled: The Renewed Eruption of Mount St. Helens, 2004-2006. U.S. Geological Survey Professional Paper 1750, Ch. 26, pp. 543-572.

Gerlach, T. M., McGee, K. A., 1994. Total sulfur dioxide emissions and pre-eruption vaporsaturated magma at Mount St. Helens, 1980-88. Geophysical Research Letters 21, 2833-2836.

Gertisser, R., Keller, J., 2003. Temporal variations in magma composition at Merapi Volcano (Central Java, Indonesia): magmatic cycles during the past 2000 years of explosive activity. Journal of Volcanology and Geothermal Research 123, 1-23. 
Geschwind, C-H., Rutherford, M., 1995. Crystallization of microlites during magma ascent: the fluid mechanics of 1980-1986 eruptions at Mount St Helens. Bulletin of Volcanology 57, 356-370.

Giggenbach, W., 1996. Chemical Composition of Volcanic Gases. In: Monitoring and Mitigation of Volcano Hazards. Springer Berlin Heidelberg, pp. 221-256.

Girona, T., Costa, F., Schubert, G., 2015. Degassing during quiescence as a trigger of magma ascent and volcanic eruptions. Scientific Reports 5.

Girona, T., Costa, F., Newhall, C., Taisne, B., 2014. On depressurization of volcanic magma reservoirs by passive degassing. Journal of Geophysical Research: Solid Earth 119, 8667- 8687.

Glicken, H., 1998. Rockslide-debris avalanche of May 18, 1980, Mount St. Helens volcano. Washington: Bulletin of the Geological Survey of Japan 49, 55-106.

Goff, F., Janik, C. J., Delgado, H., Werner, C., Counce, D., Stimac, J. A., Siebe, C., Love, S. P., Williams, S. N., Fischer, T., Johnson, L., 1998. Geochemical surveillance of magmatic volatiles at Popocatépetl volcano, Mexico. Geological Society of America Bulletin 110, 695-710.

González, M. B., Ramírez, J. J., Navarro, C., 2002. Summary of the historical eruptive activity of Volcán De Colima, Mexico 1519-2000. Journal of Volcanology and Geothermal Research 117, 21-46.

Gorbach, N., Portnyagin, M., 2011. Geology and petrology of the lava complex of Young Shiveluch Volcano, Kamchatka. Petrology 19, 134-166.

Gorelchik, V., Shirokov, V., Firstov, P., Chubarova, O., 1997. Shiveluch volcano: seismicity, deep structure and forecasting eruptions (Kamchatka). Journal of Volcanology and Geothermal Research 78, 121-137.

Gorshkov, G., 1959. Gigantic eruption of the volcano Bezymianny. Bulletin Volcanologique 20, 77-109.

Gottsmann, J., Odbert, H., 2014. The effects of thermomechanical heterogeneities in island arc crust on time-dependent preeruptive stresses and the failure of an andesitic reservoir. Journal of Geophysical Research: Solid Earth 119, 4626-4639.

Gourgaud, A., Fichaut, M., Joron, J-L., 1989. Magmatology of Mt. Pelée (Martinique, F.W.I.). I: Magma mixing and triggering of the 1902 and 1929 Pelean nuées ardentes. Journal of Volcanology and Geothermal Research 38, 143-169.

Grapenthin, R., Freymueller, J. T., Kaufman, A. M., 2013a. Geodetic observations during the 2009 eruption of Redoubt Volcano, Alaska. Journal of Volcanology and Geothermal Research 259, 115-132.

Grapenthin, R., Freymueller, J. T., Serovetnikov, S. S., 2013b. Surface deformation of Bezymianny Volcano, Kamchatka, recorded by GPS: the eruptions from 2005 to 2010 and long-term, long-wavelength subsidence. Journal of Volcanology and Geothermal Research 263, 58-74. 
Grutter, M., Basaldud, R., Rivera, C., Harig, R., Junkerman, W., Caetano, E., DelgadoGranados, H., 2008. $\mathrm{SO}_{2}$ emissions from Popocatépetl volcano: emission rates and plume imaging using optical remote sensing techniques. Atmospheric Chemistry and Physics 8, 6655- 6663.

Hammer, J., Cashman, K., Voight, B., 2000. Magmatic processes revealed by textural and compositional trends in Merapi dome lavas. Journal of Volcanology and Geothermal Research 100, 165-192.

Harris, A. J., Rose, W. I., Flynn, L. P., 2003. Temporal trends in lava dome extrusion at Santiaguito 1922-2000. Bulletin of Volcanology 65, 77-89.

Harris, G. W., 1994. The petrology and petrography of lava from the 1986 eruption of Augustine volcano. Master's Thesis, Fairbanks, Alaska, $131 \mathrm{p}$.

Hautmann, S., Witham, F., Christopher, T., Cole, P., Linde, A. T., Sacks, I. S., Sparks, R. S. J., 2014. Strain field analysis on Montserrat (W.I.) as tool for assessing permeable flow paths in the magmatic system of Soufrière Hills Volcano. Geochemistry, Geophysics, Geosystems 15, 676-690.

Henney, L., Rodríguez, L., Watson, I., 2012. A comparison of $\mathrm{SO}_{2}$ retrieval techniques using mini-UV spectrometers and ASTER imagery at Lascar volcano, Chile. Bulletin of Volcanology 74, 589-594.

Hildreth, W., 2004. Volcanological perspectives on Long Valley, Mammoth Mountain, and Mono Craters: several contiguous but discrete systems. Journal of Volcanology and Geothermal Research 136, 169-198.

Hincks, T., Komorowski, J-C., Sparks, S., Aspinall, W., 2014. Retrospective analysis of uncertain eruption precursors at La Soufrière volcano, Guadeloupe, 1975-77: volcanic hazard assessment using a Bayesian Belief Network approach. Journal of Applied Volcanology 3, 3.

Hirabayashi, J., Ohba, T., Nogami, K., Yoshida, M., 1995. Discharge rate of $\mathrm{SO}_{2}$ from Unzen volcano, Kyushu, Japan. Geophysical Research Letters 22, 1709-1712.

Hobbs, P. V., Radke, L. F., Lyons, J. H., Ferek, R. J., Coffman, D. J., Casadevall, T. J., 1991. Airborne measurements of particle and gas emissions from the 1990 volcanic eruptions of Mount Redoubt. Journal of Geophysical Research: Atmospheres 96, 18735-18752.

Hone, D., Mahony, S., Sparks, R., Martin, K., 2007. Cladistic analysis applied to the classification of volcanoes. Bulletin of Volcanology 70, 203-220.

Humaida, H., 2008. $\mathrm{SO}_{2}$ Emission Measurement By Doas (Differential Optical Absorption Spectroscopy) and Cospec (Correlation Spectroscopy) At Merapi Volcano (Indoensia). Indonesian Journal of Chemistry 8, 151-157.

Humphreys, M., Christopher, T., Hards, V., 2009. Microlite transfer by disaggregation of mafic inclusions following magma mixing at Soufrière Hills volcano, Montserrat. Contributions to Mineralogy and Petrology 157, 609-624. 
1661 Humphreys, M., Blundy, J., Sparks, R., 2008. Shallow-level decompression

1662 crystallisation and deep magma supply at Shiveluch Volcano. Contributions to

1663 Mineralogy and Petrology 155, 45-61.

1664 Humphreys, M. C. S., Blundy, J. D., Sparks, R. S. J., 2006. Magma Evolution and Open1665 System Processes at Shiveluch Volcano: Insights from Phenocryst Zoning. Journal of 1666 Petrology 47, 2303-2334.

1667 Japan Meteorological Agency, 1996. Unzendake, National Catalogue of the Active 1668 Volcanoes in Japan, second Edition. Japan Meteorological Agency, in Japanese.

1669 Jaquet, O., Carniel, R., Sparks, S., Thompson, G., Namar, R., Cecca, M. D., 2006. DEVIN: 1670 A forecasting approach using stochastic methods applied to the Soufrière Hills 1671 Volcano. Journal of Volcanology and Geothermal Research 153, 97-111.

1672 Jaupart, C., Allègre, C. J., 1991. Gas content, eruption rate and instabilities of eruption 1673 regime in silicic volcanoes . Earth and Planetary Science Letters 102, 413-429.

1674 Jaupart, C., Vergniolle, S., 1989. The generation and collapse of a foam layer at the 1675 roof of a basaltic magma chamber. Journal of Fluid Mechanics, 203, 347-380.

1676 Kienle, J., Lalla, D., Pearson, C., Barrett, S., 1979. Search for shallow magma

1677

1678

1679

1680

1681

1682

1683

1684

1685

1686

1687

1688

1689

1690

1691

1692

1693

1694

1695

1696

1697

1698

1699

1700

accumulations at Augustine volcano. Tech. rep., Geophysical Institute, University of Alaska Fairbanks, final report to U.S. Department of Energy, 157 pp.

Kilburn, C. R., 2003. Multiscale fracturing as a key to forecasting volcanic eruptions. Journal of Volcanology and Geothermal Research 125, 271-289.

Kohno, Y., Matsushima, T., Shimizu, H., 2008. Pressure sources beneath Unzen Volcano inferred from leveling and GPS data. Journal of Volcanology and Geothermal Research 175, 100-109.

Korzhinsky, M. A., Botcharnikov, R. E., Tkachenko, S. I., Steinberg, G. S., 2002. Decadelong study of degassing at Kudriavy volcano, Iturup, Kurile Islands (1990-1999): Gas temperature and composition variations, and occurrence of 1999 phreatic eruption. Earth, Planets and Space 54, 337-347.

Koulakov, I., Gordeev, E. I., Dobretsov, N. L., Vernikovsky, V. A., Senyukov, S., Jakovlev, A., Jaxybulatov, K., 2013. Rapid changes in magma storage beneath the Klyuchevskoy group of volcanoes inferred from time-dependent seismic tomography. Journal of Volcanology and Geothermal Research 263, 75-91, Magma System Response to Edifice Collapse.

Lacroix, A., 1904. La Montagne Pelée et ses éruptions. Masson et Cie, Paris.

Larsen, J. F., Nye, C. J., Coombs, M. L., Tilman, M., Izbekov, P., Cameron, C., 2010. Petrology and Geochemistry of the 2006 Eruption of Augustine Volcano. In: Power, J. A., Coombs, M. L., Freymueller, J. T. (Eds.), The 2006 Eruption of Augustine Volcano, Alaska. U.S. Geological Survey Professional Paper 1769, Ch. 15, pp. 335-382.

Lavallée, Y., Meredith, P. G., Dingwell, D. B., Hess, K-U., Wassermann, J., Cordonnier, B., Gerik, A., Kruhl, J. H., 2008. Seismogenic lavas and explosive eruption forecasting. Nature 453, 507-510. 
1701

1702

1703

1704

1705

1706

1707

1708

1709

1710

1711

1712

1713

1714

1715

1716

1717

1718

1719

1720

1721

1722

1723

1724

1725

1726

1727

1728

1729

1730

1731

1732

1733

1734

1735

1736

1737

1738

1739

1740

1741

Le Pennec, J-L., Ruiz, G. A., Ramón, P., Palacios, E., Mothes, P., Yepes, H., 2012. Impact of tephra falls on Andean communities: The influences of eruption size and weather conditions during the 1999-2001 activity of Tungurahua volcano, Ecuador. Journal of Volcanology and Geothermal Research 217-218, 91-103.

Lee, C-W., Lu, Z., Jung, H-S., Won, J-S., Dzurisin, D., 2010. Surface Deformation of Augustine Volcano, 1992-2005, from Multiple-Interferogram Processing Using a Refined Small Baseline Subset (SBAS) Interferometric Synthetic Aperture Radar (InSAR) Approach. In: Power, J. A., Coombs, M. L., Freymueller, J. T. (Eds.), The 2006 Eruption of Augustine Volcano, Alaska. U.S. Geological Survey Professional Paper 1769, Ch. 18, pp. 453-467.

Lesne, P., Kohn, S. C., Blundy, J., Witham, F., Botcharnikov, R. E., Behrens, H., 2011. Experimental Simulation of Closed-System Degassing in the System Basalt- $\mathrm{H}_{2} \mathrm{O}-\mathrm{CO}_{2}$ S-Cl. Journal of Petrology 52, 1737-1762.

Lipman, P. W., Mullineaux, D. R., 1981. The 1980 Eruptions of Mount St. Helens, Washington. U.S. 1250. Geological Survey Professional Paper.

Lisowski, M., Dzurisin, D., Denlinger, R. P., Iwatsubo, E. Y., 2008. Analysis of GPSMeasured Deformation Associated with the 2004-2006 Dome-Building Eruption of Mount St. Helens, Washington. In: Sherrod, D. R., Scott, W. E., Stauffer, P. H. (Eds.), A Volcano Rekindled: The Renewed Eruption of Mount St. Helens, 2004-2006. U.S. Geological Survey Professional Paper 1750, Ch. 15, pp. 301-334.

Lopez, T., Ushakov, S., Izbekov, P., Tassi, F., Cahill, C., Neill, O., Werner, C., 2013. Constraints on magma processes, subsurface conditions, and total volatile flux at Bezymianny Volcano in 2007-2010 from direct and remote volcanic gas measurements. Journal of Volcanology and Geothermal Research 263, 92-107.

Luhr, J. F., 2002. Petrology and geochemistry of the 1991 and 1998-1999 lava flows from Volcán de Colima, México: implications for the end of the current eruptive cycle. Journal of Volcanology and Geothermal Research 117, 169-194.

Luhr, J. F., Carmichael, I. S., 1990. Petrological monitoring of cyclical eruptive activity at Volcán Colima, Mexico. Journal of Volcanology and Geothermal Research 42, 235260.

Luhr, J. F., Carmichael, I. S., 1980. The Colima Volcanic Complex, Mexico. I. PostCaldera Andesites From Volcán Colima. Contributions to Mineralogy and Petrology 71, 343-372.

Mader, H., Llewellin, E., Mueller, S., 2013. The rheology of two-phase magmas: A review and analysis . Journal of Volcanology and Geothermal Research 257, 135158.

Major, J., Dzurisin, D., Schilling, S., Poland, M., 2009. Monitoring lava-dome growth during the 2004-2008 Mount St. Helens, Washington, eruption using oblique terrestrial photography. Earth and Planetary Science Letters 286, 243-254.

Manga, M., Castro, J., Cashman, K. V., Loewenberg, M., 1998. Rheology of bubblebearing magmas. Journal of Volcanology and Geothermal Research 87, 15-28. 
Marsh, B. D., 2015. Chapter 8-Magma Chambers . In: Sigurdsson, H. et al., (Eds.), The Encyclopedia of Volcanoes, 2nd Edition. Academic Press, pp. 343-362.

Martel, C., Ali, A. R., Poussineau, S., Gourgaud, A., Pichavant, M., 2006. Basaltinherited microlites in silicic magmas: Evidence from Mount Pelée (Martínique, French West Indes). Geology 34, 905-908.

Martel, C., Pichavant, M., Bourdier, J-L., Traineau, H., Holtz, F., Scaillet, B., 1998. Magma storage conditions and control of eruption regime in silicic volcanoes: experimental evidence from Mt. Pelée. Earth and Planetary Science Letters 156, 8999.

Marzocchi, W., Sandri, L., Gasparini, P., Newhall, C., Boschi, E., 2004. Quantifying probabilities of volcanic events: the example of volcanic hazard at Vesuvius. Journal of Geophysical Research 109, 3-20. Mastin, L. G., 1994. Explosive tephra emissions at Mount St. Helens, 1989-1991: The violent escape of magmatic gas following storms? Geological Society of America Bulletin 106, 175- 185.

Mather, T. A., Tsanev, V. I., Pyle, D. M., McGonigle, A. J. S., Oppenheimer, C., Allen, A. G., 2004. Characterization and evolution of tropospheric plumes from Lascar and Villarrica volcanoes, Chile. Journal of Geophysical Research: Atmospheres 109.

Matthews, S. J., Sparks, R. S. J., Gardeweg, M. C., 1999. The Piedras Grandes-Soncor Eruptions, Lascar Volcano, Chile; Evolution of a Zoned Magma Chamber in the Central Andean Upper Crust. Journal of Petrology 40, 1891-1919.

Matthews, S. J., Gardeweg, M. C., Sparks, R. S. J., 1997. The 1984 to 1996 cyclic activity of Lascar Volcano, northern Chile: cycles of dome growth, dome subsidence, degassing and explosive eruptions. Bulletin of Volcanology 59, 72-82.

Matthews, S. J., Jones, A. P., Gardeweg, M. C., 1994. Lascar Volcano, Northern Chile; Evidence for Steady-State Disequilibrium. Journal of Petrology 35, 401-432.

Mattioli, G. S., Herd, R. A., Strutt, M. H., Ryan, G., Widiwijayanti, C., Voight, B., 2010. Long term surface deformation of Soufrière Hills Volcano, Montserrat from GPS geodesy: Inferences from simple elastic inverse models. Geophysical Research Letters 37.

McGee, K. A., Doukas, M. P., McGimsey, R. G., Neal, C. A., Wessels, R. L., 2010. Seismic Precursors to Volcanic Explosions During the 2006 Eruption of Augustine Volcano. In: Power, J. A., Coombs, M. L., Freymueller, J. T. (Eds.), The 2006 Eruption of Augustine Volcano, Alaska. U.S. Geological Survey Professional Paper 1769, Ch. 26, pp. 609-627. Sciences 33, 461-491. 37-41. 
Menard, G., Moune, S., Vlastélic, I., Aguilera, F., Valade, S., Bontemps, M., González, R., 2014. Gas and aerosol emissions from Lascar volcano (Northern Chile): Insights into the origin of gases and their links with the volcanic activity. Journal of Volcanology and Geothermal Research 287, 51-67.

Mercalli, G., 1907. Vulcani Attivi Della Terra. Milano: Ulrico Hoefli.

Métrich, N., Bertagnini, A., Di Muro, A., 2010. Conditions of Magma Storage, Degassing and Ascent at Stromboli: New Insights into the Volcano Plumbing System with Inferences on the Eruptive Dynamics. Journal of Petrology 51, 603-626.

Michaut, C., Ricard, Y., Bercovici, D., Sparks, R. S. J., 2013. Eruption cyclicity at silicic volcanoes potentially caused by magmatic gas waves. Nature Geoscience 6, 856-860.

Miller, A. D., Stewart, R. C., White, R. A., Luckett, R., Baptie, B. J., Aspinall, W. P., Latchman, J. L., Lynch, L. L., Voight, B., 1998. Seismicity associated with dome growth and collapse at the Soufriere Hills Volcano, Montserrat. Geophysical Research Letters 25, 3401-3404.

Miller, T., Chouet, B., 1994. The 1989-1990 eruptions of Redoubt Volcano: an introduction. Journal of Volcanology and Geothermal Research 62, 1-10.

Miller, T. P., 1994. Dome growth and destruction during the 1989-1990 eruption of Redoubt volcano. Journal of Volcanology and Geothermal Research 62, 197-212.

Molina, I., Kumagai, H., Le Pennec, J. L., Hall, M., 2005. Three-dimensional P-wave velocity structure of Tungurahua Volcano, Ecuador. Journal of Volcanology and Geothermal Research 147, 144-156.

Moore, G., Carmichael, I. S. E., 1998. The hydrous phase equilibria (to 3 kbar) of an andesite and basaltic andesite from western Mexico: constraints on water content and conditions of phenocryst growth. Contributions to Mineralogy and Petrology 130, 304-319.

Mora, J., Macías, J., Saucedo, R., Orlando, A., Manetti, P., Vaselli, O., 2002. Petrology of the 1998-2000 products of Volcán de Colima, México. Journal of Volcanology and Geothermal Research 117, 195-212.

Moran, S. C., Newhall, C., Roman, D. C., 2011. Failed magmatic eruptions: late-stage cessation of magma ascent. Bulletin of Volcanology 73, 115-122.

Moran, S. C., Malone, S. D., Qamar, A. I., Thelen, W. A., Wright, A. K., Caplan-Auerbach, J., 2008. Seismicity Associated with Renewed Dome Building at Mount St. Helens, 2004-2005. In: Sherrod, D. R., Scott, W. E., Stauffer, P. H. (Eds.), A Volcano Rekindled: The Renewed Eruption of Mount St. Helens, 2004-2006. U.S. Geological Survey Professional Paper 1750, Ch. 2, pp. 27-60.

Moran, S. C., 1994. Seismicity at Mount St. Helens, 1987-1992: Evidence for repressurization of an active magmatic system. Journal of Geophysical Research: Solid Earth 99, 4341- 4354. 
1819

1820

1821

1822

1823

1824

1825

1826

1827

1828

1829

1830

1831

1832

1833

1834

1835

1836

1837

1838

1839

1840

1841

1842

1843

1844

1845

1846

1847

1848

1849

1850

1851

1852

1853

1854

1855

1856

Musumeci, C., Gresta, S., Malone, S. D., 2002. Magma system recharge of Mount St. Helens from precise relative hypocenter location of microearthquakes. Journal of Geophysical Research, 107.

Murphy, M. D., Sparks, R. S. J., Barclay, J., Carroll, M. R., Brewer, T. S., 2000. Remobilization of Andesite Magma by Intrusion of Mafic Magma at the Soufrière Hills Volcano, Montserrat, West Indies. Journal of Petrology 41, 21-42.

Nakada, S., Motomura, Y., 1999. Petrology of the 1991-1995 eruption at Unzen: effusion pulsation and groundmass crystallization. Journal of Volcanology and Geothermal Research 89, 173-196.

Nakada, S., Shimizu, H., Ohta, K., 1999. Overview of the 1990-1995 eruption at Unzen Volcano. Journal of Volcanology and Geothermal Research 89, 1-22.

Nakamura, M., 1995. Continuous mixing of crystal mush and replenished magma in the ongoing Unzen eruption. Geology 23, 807-810.

Neave, D. A., Passmore, E., Maclennan, J., Fitton, G., Thordarson, T., 2013. CrystalMelt Relationships and the Record of Deep Mixing and Crystallization in the AD 1783 Laki Eruption, Iceland. Journal of Petrology.

Neri, A., Aspinall, W., Cioni, R., Bertagnini, A., Baxter, P., Zuccaro, G., Andronico, D., Barsotti, S., Cole, P., Esposti Ongaro, T., Hincks, T., Macedonio, G., Papale, P., Rosi, M., Santacroce, R., Woo, G., 2008. Developing an Event Tree for probabilistic hazard and risk assessment at Vesuvius. Journal of Volcanology and Geothermal Research 178, 397-415.

Neuberg, J., 2000. Characteristics and causes of shallow seismicity in andesite volcanoes. Philosophical Transactions of the Royal Society of London A: Mathematical, Physical and Engineering Sciences 358, 1533-1546.

Newhall, C. G., Hoblitt, R. P., 2002. Constructing event trees for volcanic crises. Bulletin of Volcanology 64, 3-20.

Newhall, C., Melson, W., 1983. Explosive activity associated with the growth of volcanic domes. Journal of Volcanology and Geothermal Research 17, 111-131.

Newhall, C. G., Self, S., 1982. The volcanic explosivity index (VEI) an estimate of explosive magnitude for historical volcanism. Journal of Geophysical Research: Oceans 87, 1231- 1238.

Nichols, M., Malone, S., Moran, S., Thelen, W., Vidale, J., 2011. Deep long-period earthquakes beneath Washington and Oregon volcanoes. Journal of Volcanology and Geothermal Research 200, 116-128.

Nishi, K., Ono, H., Mori, H., 1999. Global positioning system measurements of ground deformation caused by magma intrusion and lava discharge: the 1990-1995 eruption at Unzendake volcano, Kyushu, Japan. Journal of Volcanology and Geothermal Research 89, 23-34. 
1857 Núñez-Cornú, F., Nava, F., De la Cruz-Reyna, S., Jiménez, Z., Valencia, C., García1858 Arthur, R., 1994. Seismic activity related to the 1991 eruption of Colima Volcano, 1859 Mexico. Bulletin of Volcanology 56, 228-237.

1860 Nye, C. J., Swanson, S. E., Avery, V. F., Miller, T. P., 1994. Geochemistry of the 198918611990 eruption of Redoubt volcano: Part I. Whole-rock major and trace-element 1862 chemistry. Journal of Volcanology and Geothermal Research 62, 429-452.

1863 Odbert, H. M., Ryan, G. A., Mattioli, G. S., Hautmann, S., Gottsmann, J., Fournier, N., 1864 1865 Herd, R. A., 2014a. Volcano geodesy at the Soufrière Hills Volcano, Montserrat: a review. Geological Society, London, Memoirs 39, 195-217.

Odbert, H. M., Stewart, R. C., Wadge, G., 2014b. Cyclic phenomena at the Soufrière Hills Volcano, Montserrat. Geological Society, London, Memoirs 39, 41-60.

Ogburn, S., Loughlin, S., Calder, E., 2015. The association of lava dome growth with major explosive activity (VEI 4): DomeHaz, a global dataset. Bulletin of Volcanology 77.

Ogburn, S. E., 2013. DomeHaz: Dome-forming eruptions database. VHub. https://vhub.org/groups/domedatabase.

Oppenheimer, C., Scaillet, B., Martin, R. S., 2011. Sulfur Degassing From Volcanoes: Source Conditions, Surveillance, Plume Chemistry and Earth System Impacts. Reviews in Mineralogy and Geochemistry 73, 363-421.

Ozerov, A., Ariskin, A., Kyle, P., Bogoyavlenskaya, G., Karpenko, S., 1997.

Petrologicalgeochemical model for genetic relationships between basaltic and andesitic magmatism of Klyuchevskoy and Bezymianny volcanoes, Kamchatka. Petrology 5, 550-569.

Pallister, J. S., Diefenbach, A. K., Burton, W. C.,Muñoz, J., Griswold, J. P., Lara, L. E., Lowenstern, J. B., Valenzuela, C. E., 2013. The Chaitén rhyolite lava dome: Eruption sequence, lava dome volumes, rapid effusion rates and source of the rhyolite magma. Andean Geology 40, 277-294.

Pallister, J. S., Thornber, C. R., Cashman, K. V., Clynne, M. A., Lowers, H. A., Mandeville, C. W., Brownfield, I. K., Meeker, G. P., 2008. Petrology of the 2004-2006 Mount St. Helens Lava Dome-Implications for Magmatic Plumbing and Eruption Triggering. In: Sherrod, D. R., Scott, W. E., Stauffer, P. H. (Eds.), A Volcano Rekindled: The Renewed Eruption of Mount St. Helens, 2004-2006. U.S. Geological Survey Professional Paper 1750, Ch. 30, pp. 647-702.

Pallister, J. S., Hoblitt, R. P., Crandell, D. R., Mullineaux, D. R., 1992. Mount St. Helens a decade after the 1980 eruptions: magmatic models, chemical cycles, and a revised hazard assessment. Bulletin of Volcanology 54, 126-146.

Perret, F., 1937. The eruption of Mt. Pelée, 1929-1932. Carnegie Institute of Washington Publication, v. 458, 126 pp. 
1895 Petrosino, S., Cusano, P., La Rocca, M., Galluzzo, D., Orozco-Rojas, J., Bretón, M., 1896 Ibáñez, J., Del Pezzo, E., 2011. Source location of long period seismicity at Volcán de 1897 Colima, México. Bulletin of Volcanology 73, 887-898.

1898 Phillipson, G., Sobradelo, R., Gottsmann, J., 2013. Global volcanic unrest in the $21^{\text {st }}$ 1899 century: An analysis of the first decade. Journal of Volcanology and Geothermal 1900 Research 264, 183- 196.

1901 Pinel, V., Albino, F., 2013. Consequences of volcano sector collapse on magmatic 1902 storage zones: Insights from numerical modeling. Journal of Volcanology and 1903 Geothermal Research 252, 29-37.

1904 Pinel, V., Jaupart, C., 2005. Some consequences of volcanic edifice destruction for 1905 eruption conditions . Journal of Volcanology and Geothermal Research 145, 68-80.

1906 Pinel, V., Jaupart, C., 2000. The effect of edifice load on magma ascent beneath a 1907 volcano. Philosophical Transactions of the Royal Society of London A: Mathematical, 1908 Physical and Engineering Sciences 358, 1515-1532.

1909 Plail, M., Barclay, J., Humphreys, M. C. S., Edmonds, M., Herd, R. A., Christopher, T. E., 1910 2014. Chapter 18 Characterization of mafic enclaves in the erupted products of 1911 Soufrière Hills Volcano, Montserrat, 2009 to 2010. Geological Society, London, 1912 Memoirs 39, 343-360.

1913 Platt, U., Stutz, J., 2008. Differential Absorption Spectroscopy. In: Differential Optical 1914 Absorption Spectroscopy. Physics of Earth and Space Environments. Springer Berlin 1915 Heidelberg, pp. 135-174.

1916 Power, J. A., Lalla, D. J., 2010. Seismic Observations of Augustine Volcano, 19701917 2007. In: Power, J. A., Coombs, M. L., Freymueller, J. T. (Eds.), The 2006 Eruption of 1918 Augustine Volcano, Alaska. U.S. Geological Survey Professional Paper 1769, Ch. 1, pp. 1919 3-40.

1920 Power, J. A., Stihler, S. D., Chouet, B. A., Haney, M. M., Ketner, D. M., 2013. Seismic 1921 observations of Redoubt Volcano, Alaska-1989-2010 and a conceptual model of the 1922 Redoubt magmatic system. Journal of Volcanology and Geothermal Research 259, 1923 31-44.

1924 Power, J. A., Nye, C. J., Coombs, M. L., Wessels, R. L., Cervelli, P. F., Dehn, J., Wallace, K. 1925 L., Freymueller, J. T., Doukas, M. P., 2006. The reawakening of Alaska's Augustine 1926 volcano. Eos, Transactions American Geophysical Union 87, 373-377.

1927 Pritchard, M. E., Simons, M., 2002. A satellite geodetic survey of large-scale 1928 deformation of volcanic centres in the central Andes. Nature 418, 167-171.

1929 Pyle, D., 2000. Sizes of volcanic eruptions. In: Sigurdsson, H. (Ed.), Encyclopaedia of 1930 Volcanoes. Academic, Sydney, pp. 263-269.

1931 Ratdomopurbo, A., Beauducel, F., Subandriyo, J., Nandaka, I. M. A., Newhall, C. G., 1932 Suhama, Sayudi, D. S., Suparwaka, H., Sunarta, 2013. Overview of the 2006 eruption 1933 of Mt. Merapi. Journal of Volcanology and Geothermal Research 261, 87-97. 
1934

1935

1936

1937

1938

1939

1940

1941

1942

1943

1944

1945

1946

1947

1948

1949

1950

1951

1952

1953

1954

1955

1956

1957

1958

1959

1960

1961

1962

1963

1964

1965

1966

1967

1968

1969

1970

1971

Ratdomopurbo, A., Poupinet, G., 2000. An overview of the seismicity of Merapi volcano (Java, Indonesia), 1983-1994. Journal of Volcanology and Geothermal Research 100, 193-214.

Reubi, O., Blundy, J., 2009. A dearth of intermediate melts at subduction zone volcanoes and the petrogenesis of arc andesites . Nature 461, 1269-1273.

Ripepe, M., Donne, D. D., Genco, R., Maggio, G., Pistolesi, M.,Marchetti, E., Lacanna, G., Ulivieri, G., Poggi, P.,2015. Volcano seismicity and ground deformation unveil the gravity-driven magma discharge dynamics of a volcanic eruption. Nature Communications 6.

Rittmann, A., 1962. Volcanoes and their Activity. New York: John Wiley \& Sons.

Roberge, J., Delgado-Granados, H., Wallace, P. J., 2009. Mafic magma recharge supplies high $\mathrm{CO}_{2}$ and $\mathrm{SO}_{2}$ gas fluxes from Popocatépetl volcano, Mexico. Geology 37, 107-110.

Robin, C., Camus, G., Gourgaud, A., 1991. Eruptive and magmatic cycles at Fuego de Colima volcano (Mexico). Journal of Volcanology and Geothermal Research 45, 209225.

Rodríguez, L. A., Watson, I. M., Rose, W. I., Branan, Y. K., Bluth, G. J., Chigna, G., Matías, O., Escobar, D., Carn, S. A., Fischer, T. P., 2004. $\mathrm{SO}_{2}$ emissions to the atmosphere from active volcanoes in Guatemala and El Salvador, 1999-2002. Journal of Volcanology and Geothermal Research 138, 325-344.

Roman, D. C., Cashman, K. V., Gardner, C. A., Wallace, P. J., Donovan, J. J., 2006. Storage and interaction of compositionally heterogeneous magmas from the 1986 eruption of Augustine Volcano, Alaska. Bulletin of Volcanology 68, 240-254.

Roman, D. C., Power, J. A., Moran, S. C., Cashman, K. V., Doukas, M. P., Neal, C. A., Gerlach, T. M., 2004. Evidence for dike emplacement beneath Iliamna Volcano, Alaska in 1996 . Journal of Volcanology and Geothermal Research 130, 265-284.

Rose, W. I., 1973. Pattern and mechanism of volcanic activity at the Santiaguito Volcanic Dome, Guatemala. Bulletin of Volcanology 37, 73-94.

Rose, W.I., J., 1972. Notes on the 1902 eruption of Santa María volcano, Guatemala. Bulletin Volcanologique 36, 29-45.

Rose, W. I., Bluth, G. J. S., Ernst, G. G. J., 2000. Integrating retrievals of volcanic cloud characteristics from satellite remote sensors: a summary. Philosophical Transactions of the Royal Society of London A: Mathematical, Physical and Engineering Sciences 358, 1585- 1606.

Rose, W. I., Heiken, G., Wohletz, K., Eppler, D., Barr, S., Miller, T., Chuan, R. L., Symonds, R. B., 1988. Direct Rate Measurements of Eruption Plumes at Augustine Volcano: A Problem of Scaling and Uncontrolled Variables. Journal of Geophysical Research: Solid Earth 93, 4485-4499. 
1972

1973

1974

1975

1976

1977

1978

1979

1980

1981

1982

1983

1984

1985

1986

1987

1988

1989

1990

1991

1992

1993

1994

1995

1996

1997

1998

1999

2000

2001

2002

2003

2004

2005

2006

2007

2008

2009
Rutherford, M. J., Sigurdsson, H., Carey, S., Davis, A., 1985. The May 18, 1980, eruption of Mount St. Helens: 1. Melt composition and experimental phase equilibria. Journal of Geophysical Research: Solid Earth 90, 2929-2947.

Samaniego, P., Le Pennec, J-L., Robin, C., Hidalgo, S., 2011. Petrological analysis of the preeruptive magmatic process prior to the 2006 explosive eruptions at Tungurahua volcano (Ecuador). Journal of Volcanology and Geothermal Research 199, 69-84.

Sandri, L., Marzocchi, W., Zaccarelli, L., 2004. A new perspective in identifying the precursory patterns of eruptions. Bulletin of Volcanology 66, 263-275.

Savov, I. P., Luhr, J. F., Navarro-Ochoa, C., 2008. Petrology and geochemistry of lava and ash erupted from Volcán Colima, Mexico, during 1998-2005. Journal of Volcanology and Geothermal Research 174, 241-256.

Scandone, R., Cashman, K. V., Malone, S. D., 2007. Magma supply, magma ascent and the style of volcanic eruptions . Earth and Planetary Science Letters 253, 513-529.

Scandone, R., Malone, S. D., 1985. Magma supply, magma discharge and readjustment of the feeding system of mount St. Helens during 1980. Journal of Volcanology and Geothermal Research 23, 239-262.

Schilling, S. P., Thompson, R. A., Messerich, J. A., Iwatsubo, E. Y., 2008. Use of Digital Aerophotogrammetry to Determine Rates of Lava Dome Growth, Mount St. Helens, Washington, 2004-2005. In: Sherrod, D. R., Scott, W. E., Stauffer, P. H. (Eds.), A Volcano Rekindled: The Renewed Eruption of Mount St. Helens, 2004-2006. U.S. Geological Survey Professional Paper 1750, Ch. 8, pp. 145-168.

Scott, J. A. J., Pyle, D. M., Mather, T. A., Rose, W. I., 2013. Geochemistry and evolution of the Santiaguito volcanic dome complex, Guatemala. Journal of Volcanology and Geothermal Research 252, 92-107.

Scott, J. A., Mather, T. A., Pyle, D. M., Rose, W. I., Chigna, G., 2012. The magmatic plumbing system beneath Santiaguito Volcano, Guatemala. Journal of Volcanology and Geothermal Research 237-238, 54-68.

Scott, W. E., Sherrod, D. R., Gardner, C. A., 2008. Overview of the 2004 to 2006, and Continuing, Eruption of Mount St. Helens, Washington. In: Sherrod, D. R., Scott, W. E., Stauffer, P. H. (Eds.), A Volcano Rekindled: The Renewed Eruption of Mount St. Helens, 2004-2006. U.S. Geological Survey Professional Paper 1750, Ch. 1, pp. 3-26.

Sernageomin, 2013. Reporte de Actividad Volcánica (RAV) REGIÓN DE ANTOFAGASTA Ano 2013 Julio-Volumen 9. Tech. rep., Sernageomin. http://www.sernageomin.cl/reportesVolcanes/20130813010943279RAV_ Antofagasta_2013_julio_vol_9.pdf

Shcherbakov, V. D., Plechov, P. Y., Izbekov, P. E., Shipman, J. S., 2011. Plagioclase zoning as an indicator of magma processes at Bezymianny Volcano, Kamchatka. Contributions to Mineralogy and Petrology 162, 83-99. 
Sheldrake, T., 2014. Long-term forecasting of eruption hazards: A hierarchical approach to merge analogous eruptive histories. Journal of Volcanology and Geothermal Research 286, 15-23.

Shepherd, J. B., Tomblin, J., Woo, D., 1971. Volcano-Seismic Crisis in Montserrat, West Indies, 1966-67. Bulletin Volcanologique 35, 143-152.

Shinohara, H., 2008. Excess degassing from volcanoes and its role on eruptive and intrusive activity. Review of Geophysics 46.

Sides, I. R., Edmonds, M., Maclennan, J., Swanson, D. A., Houghton, B. F., 2014. Eruption style at Kilauea Volcano in Hawaiì linked to primary melt composition. Nature Geoscience 7, 464- 469.

Siebert, L., Simkin, T., Kimberley, P., 2010. Volcanoes of the World. Berkeley: University of California Press.

Siswowidjoyo, S., Suryo, I., Yokoyama, I., 1995. Magma eruption rates of Merapi volcano, Central Java, Indonesia during one century (1890-1992). Bulletin of Volcanology 57, 111-116.

Smith, A. L., Roobol, M. J., 1990. Mt. Pelée, Martinique; A Study of an Active Island-arc Volcano. Geological Society of America Memoirs 175, 1-110.

Smith, R., Kilburn, C., Sammonds, P., 2007. Rock fracture as a precursor to lava dome eruptions at Mount St Helens from June 1980 to October 1986. Bulletin of Volcanology 69, 681-693.

Sobradelo, R., Martí, J., 2015. Short-term volcanic hazard assessment through Bayesian inference: retrospective application to the Pinatubo 1991 volcanic crisis. Journal of Volcanology and Geothermal Research 290, 1-11.

Sobradelo, R., Bartolini, S., Martí, J., 2013. HASSET: a probability event tree tool to evaluate future volcanic scenarios using Bayesian inference. Bulletin of Volcanology 76.

Solano, J. M. S., Jackson, M. D., Sparks, R. S. J., Blundy, J. D., Annen, C., 2012. Melt Segregation in Deep Crustal Hot Zones: a Mechanism for Chemical Differentiation, Crustal Assimilation and the Formation of Evolved Magmas. Journal of Petrology.

Sparks, R. S. J., 2003. Forecasting volcanic eruptions. Earth and Planetary Science Letters 210, 1-15.

Sparks, R. S. J., 1997. Causes and consequences of pressurisation in lava dome eruptions. Earth and Planetary Science Letters 150, 177-189.

Sparks, R. S. J., Biggs, J., Neuberg, J. W., 2012. Monitoring Volcanoes. Science 335.

Sparks, R. S. J., Aspinall, W. P., 2004. Volcanic Activity: Frontiers and Challenges in Forecasting, Prediction and Risk Assessment. In: AGU Geophysical Monograph "State of the Planet"150. pp. 359-374. 
Sparks, R. S. J., Young, S. R., 2002. The eruption of Soufrière Hills Volcano, Montserrat (1995-1999): overview of scientific results. Geological Society, London, Memoirs 21, 45-69.

Spiegelhalter, D. J., 1986. Probabilistic prediction in patient management and clinical trials. Statistics in Medicine 5, 421-433.

Stasiuk, M. V., Jaupart, C., Sparks, R. S. J., 1993. On the variations of flow rate in nonexplosive lava eruptions. Earth and Planetary Science Letters 114, 505-516.

Steffke, A. M., Fee, D., Garces, M., Harris, A., 2010. Eruption chronologies, plume heights and eruption styles at Tungurahua Volcano: Integrating remote sensing techniques and infrasound. Journal of Volcanology and Geothermal Research 193, 143-160.

Stith, J. L., Hobbs, P. V., Radke, L. F., 1978. Airborne particle and gas measurements in the emissions from six volcanoes. Journal of Geophysical Research: Oceans 83, 40094017.

Straub, S. M., Martin-Del Pozzo, A. L., 2001. The significance of phenocryst diversity in tephra from recent eruptions at Popocatepetl volcano (central Mexico). Contributions to Mineralogy and Petrology 140, 487-510.

Surono, Jousset, P., Pallister, J., Boichu, M., Buongiorno, M. F., Budisantoso, A., Costa, F., Andreastuti, S., Prata, F., Schneider, D., Clarisse, L., Humaida, H., Sumartí, S., Bignami, C., Griswold, J., Carn, S., Oppenheimer, C., Lavigne, F., 2012. The 2010 explosive eruption of Java's Merapi volcano-A '100-year' event. Journal of Volcanology and Geothermal Research 241242, 121-135.

Swanson, D., Holcomb, R., 1990. Regularities in Growth of the Mount St. Helens Dacite Dome, 1980-1986. In: Fink, J. H. (Ed.), Lava Flows and Domes. Vol. 2 of IAVCEI Proceedings in Volcanology. Springer Berlin Heidelberg, pp. 3-24.

Swanson, D. A., Casadevall, T. J., Dzurisin, D., Malone, S. D., Newhall, C. G., Weaver, C. S., 1983. Predicting Eruptions at Mount St. Helens, June 1980 Through December 1982. Science 221, 1369-1376.

Swanson, S. E., Nye, C. J., Miller, T. P., Avery, V. F., 1994. Geochemistry of the 19891990 eruption of Redoubt volcano: Part II. Evidence from mineral and glass chemistry. Journal of Volcanology and Geothermal Research 62, 453-468.

Swanson, S. E., Kienle, J., 1988. The 1986 Eruption of Mount St. Augustine: Field Test of a Hazard Evaluation. Journal of Geophysical Research: Solid Earth 93, 4500-4520.

Symonds, R. B., Rose, W. I., Gerlach, T. M., Briggs, P. H., Harmon, R. S., 1990. Evaluation of gases, condensates, and $\mathrm{SO}_{2}$ emissions from Augustine volcano, Alaska: the degassing of a Cl-rich volcanic system. Bulletin of Volcanology 52, 355374.

Szakács, A., 2010. From a definition of volcano to conceptual volcanology. Geological Society of America Special Papers, 470, 67-76. 
Szakács, A., Cañón-Tapia. E., 2010. Some challenging new perspectives of volcanology. Geological Society of America Special Papers, 470, 123-140.

Tanguy, J-C., 2004. Rapid dome growth at Montagne Pelée during the early stages of the 1902-1905 eruption: a reconstruction from Lacroix's data. Bulletin of Volcanology 66, 615-621.

Tanguy, J. C., 1994. The 1902-1905 eruptions of Montagne Pelée, Martínique: anatomy and retrospection. Journal of Volcanology and Geothermal Research 60, 87107.

Taran, Y., Gavilanes, J. C., Cortés, A., 2002. Chemical and isotopic composition of fumarolic gases and the $\mathrm{SO}_{2}$ flux from Volcán de Colima, México, between the 1994 and 1998 eruptions. Journal of Volcanology and Geothermal Research 117, 105-119. Tarasewicz, J., White, R. S., Woods, A. W., Brandsdóttir, B., Gudmundsson, M. T., 2012. Magma mobilization by downward-propagating decompression of the Eyjafjallajökull volcanic plumbing system. Geophysical Research Letters 39.

Thelan, W., West, M., Senyukov, S., 2010. Seismic characterisation of the fall 2007 eruptive sequence at Bezymianny Volcano, Russia. Journal of Volcanology and Geothermal Research 194, 201-213.

Toramaru, A., Noguchi, S., Oyoshihara, S., Tsune, A., 2008. MND (microlite number density) water exsolution rate meter. Journal of Volcanology and Geothermal Research 175, 156-167.

Troll, V. R., Deegan, F. M., Jolis, E. M., Harris, C., Chadwick, J. P., Gertisser, R., Schwarzkopf, L. M., Borisova, A. Y., Bindeman, I. N., Sumarti, S., Preece, K., 2013. Magmatic differentiation processes at Merapi Volcano: inclusion petrology and oxygen isotopes. Journal of Volcanology and Geothermal Research 261, 38-49.

Turner, S. J., Izbekov, P., Langmuir, C., 2013. The magma plumbing system of Bezymianny Volcano: Insights from a 54 year time series of trace element wholerock geochemistry and amphibole compositions. Journal of Volcanology and Geothermal Research 263, 108-121.

Ui, T., Takarada, S., Yoshimoto, M., 2000. Debris avalanches. In: Sigurdsson, H. et al. (Eds.), Encyclopedia of Volcanoes. $1^{\text {st }}$ Edition. Academic Press, pp. 617-626.

Umakoshi, K., Takamura, N., Shinzato, N., Uchida, K., Matsuwo, N., Shimizu, H., 2008. Seismicity associated with the 1991-1995 dome growth at Unzen Volcano, Japan . Journal of Volcanology and Geothermal Research 175, 91-99.

USGS, 2014. Cascades Volcano Observatory Information Statement: Wednesday, April 30, 2014 16:05 UTC. Tech. rep., USGS, http://volcanoes.usgs.gov/activity/archiveupdate.php?noticeid=10035. van Manen, S. M., Dehn, J., Blake, S., 2010. Satellite thermal observations of the Bezymianny lava dome 1993-2008: Precursory activity, large explosions, and dome growth. Journal of Geophysical Research: Solid Earth 115. 
2125 Varley, N., Arámbula-Mendoza, R., Reyes-Dávila, G., Sanderson, R., Stevenson, J.,

2126 2010. Generation of Vulcanian activity and long-period seismicity at Volcán de

2127 Colima, Mexico. Journal of Volcanology and Geothermal Research 198, 45-56.

2128 Varley, N. R., Taran, Y., 2003. Degassing processes of Popocatépetl and Volcán de

2129 Colima, Mexico. Geological Society, London, Special Publications 213, 263-280.

2130 Voight, B., 1988. A method for prediction of volcanic eruptions. Nature 332, 125-

2131130.

2132 Voight, B., Constantine, E. K., Siswowidjoyo, S., Torley, R., 2000. Historical eruptions

2133 of Merapi Volcano, Central Java, Indonesia, 1768-1998. Journal of Volcanology and

2134 Geothermal Research 100, 69-138.

2135 Voight, B., Janda, R. J., Glicken, H., Douglass, P. M., 1983. Nature and mechanics of the

2136 Mount St Helens rockslide-avalanche of 18 May 1980. Géotechnique 33, 243-273.

2137 Volpe, A. M., Hammond, P. E., 1991. ${ }^{238}$ U-230Th-226 Ra disequilibria in young Mount St.

2138 Helens rocks: time constraint for magma formation and crystallization. Earth and

2139 Planetary Science Letters 107, 475-486.

2140 Wadge, G., Aspinall, W. P., 2014. A review of volcanic hazard and risk-assessment 2141 praxis at the Soufrière Hills Volcano, Montserrat from 1997 to 2011. Geological

2142 Society, London, Memoirs 39, 439-456.

2143 Wadge, G., Voight, B., Sparks, R. S. J., Cole, P. D., Loughlin, S. C., Robertson, R. E. A., 2144 2014. An overview of the eruption of Soufrière Hills Volcano, Montserrat from 2000 2145 to 2010. Geological Society, London, Memoirs 39, 1-40.

2146 Wadge, G., Herd, R., Ryan, G., Calder, E. S., Komorowski, J. C., 2010. Lava production 2147 at Soufrière Hills Volcano, Montserrat: 1995-2009. Geophysical Research Letters 37.

2148 Wallace, P. J., 2005. Volatiles in subduction zone magmas: concentrations and fluxes 2149 based on melt inclusion and volcanic gas data. Journal of Volcanology and

2150 Geothermal Research 140, 217-240.

2151 Wallace, P. J., 2003. From mantle to atmosphere: magma degassing, explosive 2152 eruptions, and volcanic volatile budgets. In: Vivo, B. D., Bodnar, R. J. (Eds.), Melt 2153 Inclusions in Volcanic Systems Methods, Applications and Problems. Vol. 5 of 2154 Developments in Volcanology. Elsevier, pp. 105-127.

2155 Wallace, P. J., Edmonds, M., 2011. The Sulfur Budget in Magmas: Evidence from Melt 2156 Inclusions, Submarine Glasses, and Volcanic Gas Emissions. Reviews in Mineralogy and Geochemistry 73, 215-246.

2158 Walter, T. R., Wang, R., Zimmer, M., Grosser, H., Lühr, B., Ratdomopurbo, A., 2007.

2159 Volcanic activity influenced by tectonic earthquakes: Static and dynamic stress

2160 triggering at Mt. Merapi. Geophysical Research Letters 34.

2161 Watts, R. B., Herd, R. A., Sparks, R. S. J., Young, S. R., 2002. Growth patterns and

2162 emplacement of the andesitic lava dome at Soufrière Hills Volcano, Montserrat.

2163 Geological Society, London, Memoirs 21, 115-152. 
2164 Webster, J. D., Mandeville, C. W., Goldoff, B., Coombs, M. L., Tappen, C., 2010.

2165 Augustine Volcano-The Influence of Volatile Components in Magmas Erupted A.D.

21662006 to 2,100 Years Before Present. In: Power, J. A., Coombs, M. L., Freymueller, J. T.

2167 (Eds.), The 2006 Eruption of Augustine Volcano, Alaska. U.S. Geological Survey

2168 Professional Paper 1769, Ch. 16, p. 383.

2169 Werner, C., Kelly, P. J., Doukas, M., Lopez, T., Pfeffer, M., McGimsey, R., Neal, C., 2013.

2170 Degassing of $\mathrm{CO}_{2}, \mathrm{SO}_{2}$, and $\mathrm{H}_{2} \mathrm{~S}$ associated with the 2009 eruption of Redoubt

2171 Volcano, Alaska. Journal of Volcanology and Geothermal Research 259, 270-284.

2172 West, M. E., 2013. Recent eruptions at Bezymianny volcano-A seismological

2173 comparison. Journal of Volcanology and Geothermal Research 263, 42-57.

2174 Whelley, P. L., Newhall, C.G., Bradley, K. E., 2015, The frequency of explosive volcanic eruptions in Southeast Asia. Bulletin of Volcanology 77.

2176

2177

2178

2179

2180

2181

2182

2183

2184

2185

2186

2187

2188

2189

2190

2191

2192

2193

2194

2195

2196

2197

2198

2199

2200

2201

2202

2203

White, R., McCausland, W., 2016. Volcano-tectonic earthquakes: A new tool for estimating intrusive volumes and forecasting eruptions. Journal of Volcanology and Geothermal Research 309, 139-155.

Witter, J. B., Kress, C. C., Newhall, C. G., 2005. Volcano Popocatepetl, Mexico. Petrology, Magma Mixing, and Immediate Sources of Volatiles for the 1994-Present Eruption. Journal of Petrology 46, 2337-2366.

Wolf, K. J., Eichelberger, J. C., 1997. Syneruptive mixing, degassing, and crystallization at Redoubt Volcano, eruption of December, 1989 to May 1990. Journal of Volcanology and Geothermal Research 75, 19-37.

Wright, H. M., Cashman, K. V., Mothes, P. A., Hall, M. L., Ruiz, A. G., Le Pennec, J-L., 2012. Estimating rates of decompression from textures of erupted ash particles produced by 1999-2006 eruptions of Tungurahua volcano, Ecuador. Geology 40, 619-622.

Yokoyama, I., 2005. Growth rates of lava domes with respect to viscosity of magmas. Annals Of Geophysics, 48.

Young, S. R., Sparks, R. S. J., Aspinall, W. P., Lynch, L. L., Miller, A. D., Robertson, R. E. A., Shepherd, J. B., 1998. Overview of the eruption of Soufrière Hills Volcano, Montserrat, 18 July 1995 to December 1997. Geophysical Research Letters 25, 33893392.

Zellmer, G. F., Sparks, R. S. J., Hawkesworth, C. J., Wiedenbeck, M., 2003a. Magma Emplacement and Remobilization Timescales Beneath Montserrat: Insights from Sr and Ba Zonation in Plagioclase Phenocrysts. Journal of Petrology 44, 1413-1431.

Zellmer, G. F., Hawkesworth, C. J., Sparks, R. S. J., Thomas, L. E., Harford, C. L., Brewer, T. S., Loughlin, S. C., 2003b. Geochemical Evolution of the Soufrière Hills Volcano, Montserrat, Lesser Antilles Volcanic Arc. Journal of Petrology 44, 1349-1374.

Zharinov, N., Demyanchuk, Y., 2008. The growth of an extrusive dome on Shiveluch Volcano, Kamchatka in 1980-2007: Geodetic observations and video surveys. Journal of Volcanology and Seismology 2, 217-227. 
Zobin, V. M., Varley, N. R., González, M., Orozco, J., Reyes, G. A., Reyes, C. A., Navarro, C., Bretón, M., 2008. Monitoring the 2004 andesitic block-lava extrusion at Volcán de Colima, México from seismic activity and $\mathrm{SO}_{2}$ emission. Journal of Volcanology and Geothermal Research 177, 367-377.

Zobin, V., Luhr, J., Taran, Y., Bretón, M., Cortés, A., De la Cruz-Reyna, S., Domınguez, T., Galindo, I., Gavilanes, J., Muñíz, J., Navarro, C., Ramírez, J., Reyes, G., Ursúa, M., Velasco, J., Alatorre, E., Santiago, H., 2002. Overview of the 1997-2000 activity of Volcán de Colima, México. Journal of Volcanology and Geothermal Research 117, 119.

\section{Figure Captions:}

\section{(1.5 column)}

Figure 1: Locations of the 15 dome-building volcanoes in this study: (a) Augustine; (b) Bezymianny; (c) Colima; (d) Kudryavy; (e) Lascar; (f) Merapi; (g) Mount St. Helens; (h) Mont Pelée; (i) Popocatépetl; (j) Redoubt; (k) Santiaguito; (l) Shiveluch; (m) Soufrière Hills Volcano; (n) Tungurahua; (o) Mount Unzen. They are all found in subduction settings: either oceanic-continental or oceanic-oceanic boundaries.

\section{(1.5 column)}

Figure 2: Binary plots indicating whether (magmatic) eruptive activity (ash explosions and lava dome growth) was recording in each year since 1800 C.E, at each of the 15 volcanoes in this study. Importantly, the red bars do not equate to continuous eruptive activity, but instead are meant to indicate the variation in longterm patterns of eruptive activity. Labels are MER - Merapi; LAS - Lascar; COL Colima; SHI - Shiveluch; SAN - Santiaguito; BEZ - Bezymianny; POP - Popocatépetl; TUN - Tungurahua; SHV - Soufrière Hills Volcano; HEL - Mount St. Helens; AUG Augustine; RED - Redoubt; UNZ - Unzen; PEL - Pelée; KUD - Kudryavy. Volcanoes with the most persistent behaviour are found towards the top of the figure, and we have highlighted issues with specifically identifying a persistent regime in older records. The record of volcanic activity is based upon the Smithsonian database (Siebert and Simkin, 2002), and references specific to each volcano that can be found in section 3 and the supplementary material.

\section{(Single column)}

Figure 3: Representative cartoons for the two different eruptive regimes that are identified in this review; (a) Episodic behaviour, where the duration a volcano remains in an eruptive state is proportionally much shorter that the duration it remains in non-eruptive state. Degassing is temporally correlated with eruptive activity, and the regime is characterised by periods of no eruptive in which degassing is negligible, which we define as inter-eruptive repose; (b) Persistent 
behaviour, where the duration a volcano remains in an eruptive state is proportionally similar to the duration it remains in non-eruptive state. Degassing is not necessarily temporally correlated with eruptive activity, and the regime is characterised by periods of no eruptive in which degassing is continuous and sustained, which we define as intra-eruptive repose. (c) A third mixed regime is characterised to identify how a volcano can exhibit both episodic and persistent behaviour in its eruptive record.

2255

2256

2257

2258

2259

2260

2261

2262

2263

2264

2265

2266

2267

2268

2269

2270

2271

2272

2273

2274

2275

2276

2277

2278

2279

2280

2281

2282

2283

2284

2285

(Double column)

Figure 4: A hierarchical construct for historical eruptive activity at dome-building volcanoes. The first sub-level of this construct identifies the two different behaviours, episodic and persistent. The second sub-level of this construct identifies two different styles of episodic and persistent behaviour that are observed in historical records, over identical timescales (i.e. between points a and b). Key characteristics for each behaviour are identified in the boxes below each cartoon.

(Double column)

Figure 5: (a) Episodic behaviour at Augustine between 1970 and 2008, consisting of four eruptive episodes lasting months (red lines represent onsets), adapted from Power and Lalla, (2010). $\mathrm{SO}_{2}$ degassing (orange) is temporally correlated with the eruptive episodes, as indicated by the data from McGee et al., (2010), overlaid on the lower chart. Black bars represent seismicity, which is elevated prior and during eruptive episodes; (b) Persistent behavior at Merapi between 1990 and 2006, with several phases of dome growth (blue bars) and associated explosions (blue vertical arrows), adapted from Ratdomopurbo et al., (2013). $\mathrm{SO}_{2}$ degassing (orange) is temporally uncorrelated with eruptive activity, as observed by the overlaid data between 1992 and 1998. Seismicity is correlated with phases of eruptive activity, as indicated by the variation in the cumulative seismic energy (red line).

(Single column)

Figure 6: Estimated effusion rate (blue dots) at Unzen between 1990-1995, from Nakada et al. (1999). This is an example of a single eruptive episode at Unzen that lasted 5 years between 1990-1995 (Fig. 2). The latter stages of the eruptive episode are characterised by crystal-rich lavas and low effusion rates. During the eruptive episode, however, there are periodic increases in effusion rate, such as in 1993.

(Single column)

Figure 7: Estimated extrusion rates (blue dots) for 23 phases of dome growth at Bezymianny volcano between 1993 and 2008, from van Manen et al., (2010). This pattern of activity is an example of a persistent regime, in which frequent periods of dome-growth occur, with a consistent long-term extrusion rate. However, the intensity and frequency of phases of dome growth can vary. The red dashed line indicates the cumulative extruded volume, in which periods of dome growth and repose can be observed. 
(Single column)

Figure 8: Example of a conceptual model for eruptive activity associated with the shallow chamber paradigm at La Soufrière, Guadeloupe, adapted from Hincks et al. (2014), where geophysical and geochemical observations at the surface are interpreted in terms of shallow crustal magmatic processes.

(Single column)

Figure 9: Schematic for the interaction of melt layers in a transcrustal magmatic system at lava dome-building volcanoes. Possible scenarios for eruptive activity and volcanic unrest; (a) complete destabilisation of the tran- scrustal system, involving deeply sourced mafic melts that provide volatiles and heat, resulting in major explosive activity; (b) partial destabilisation of the transcrustal system involving magma stored in shallow crustal regions resulting in effusive and minor explosive activity; (c) partial destabilisation of the magmatic system resulting in volcanic unrest but not eruptive activity. Importantly, this is in no way a true representation of the structure and dimensions of magmatic systems at lava dome-building volcanoes as they are found in subduction zones. Indeed, perpendicular to tectonic plate margins the arc widths of active volcanism are generally very narrow $(\sim 5 \mathrm{~km}$ or less). 


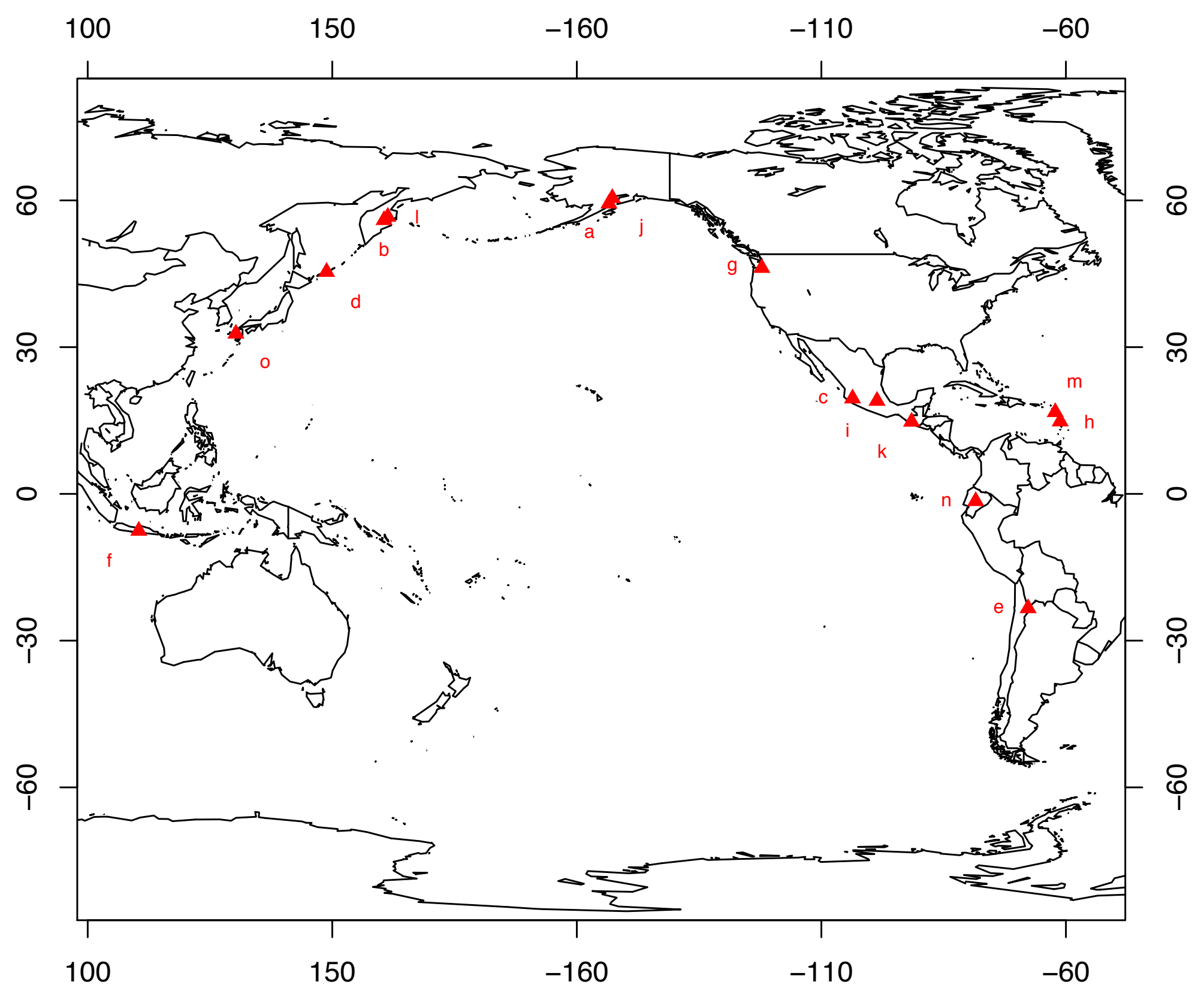




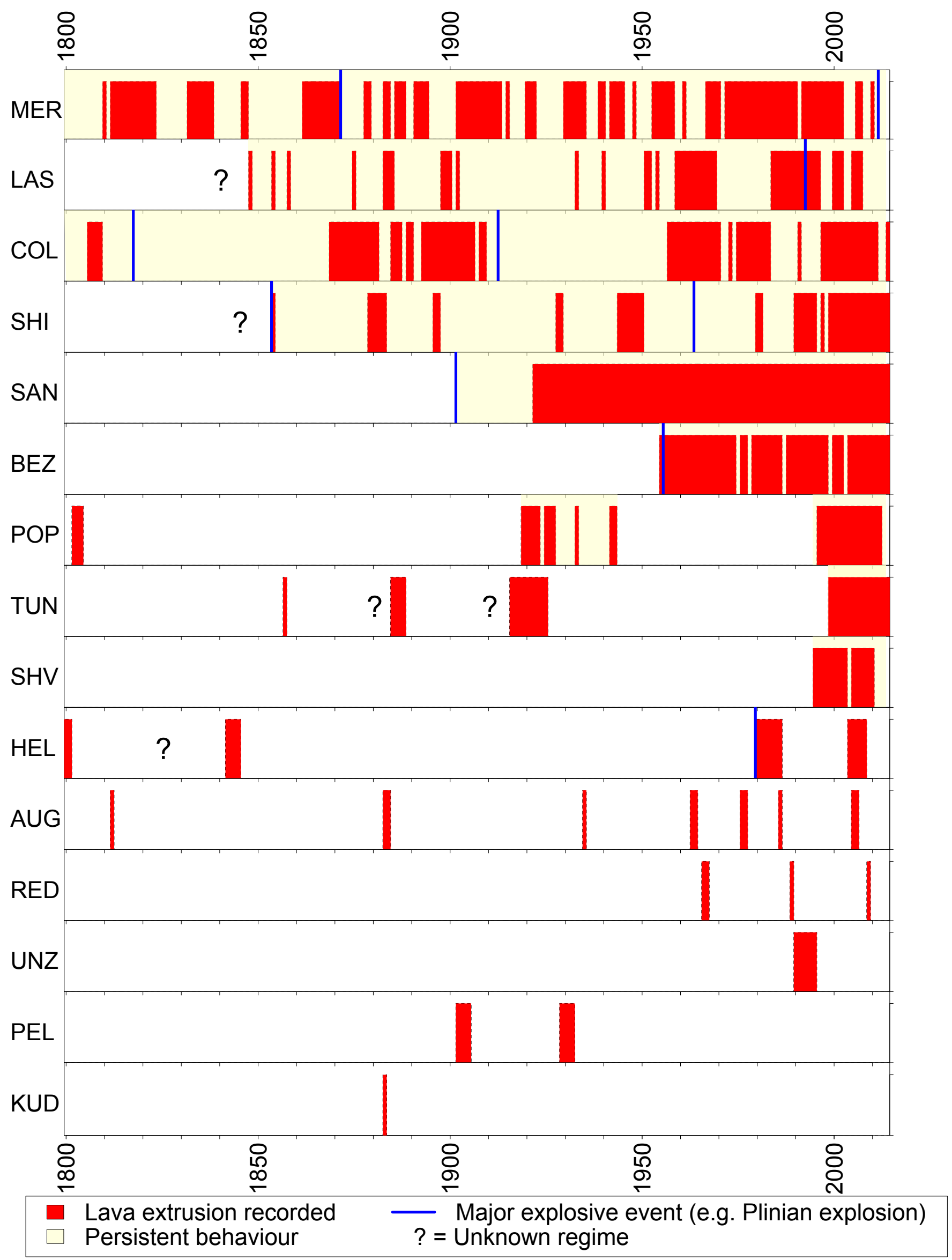




\section{(a) Episodic regime}

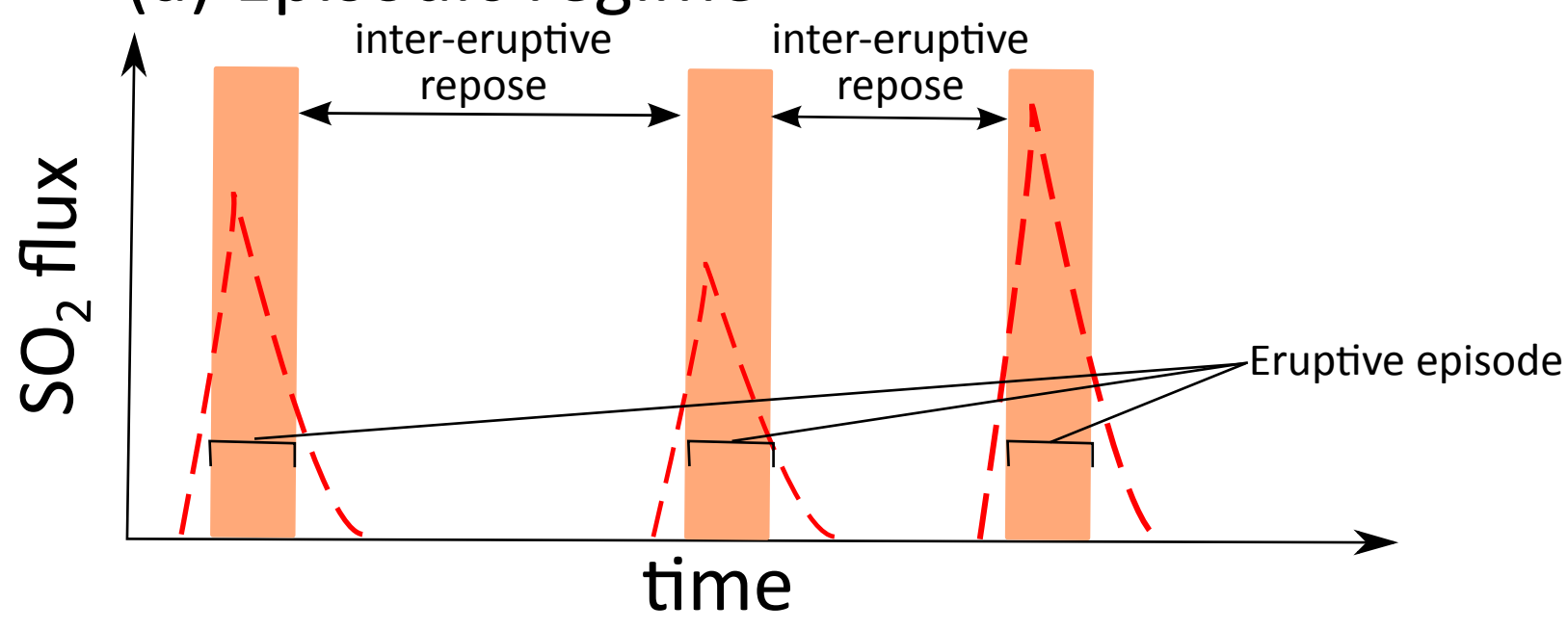

\section{(b) Persistent regime \\ intra-eruptive repose}

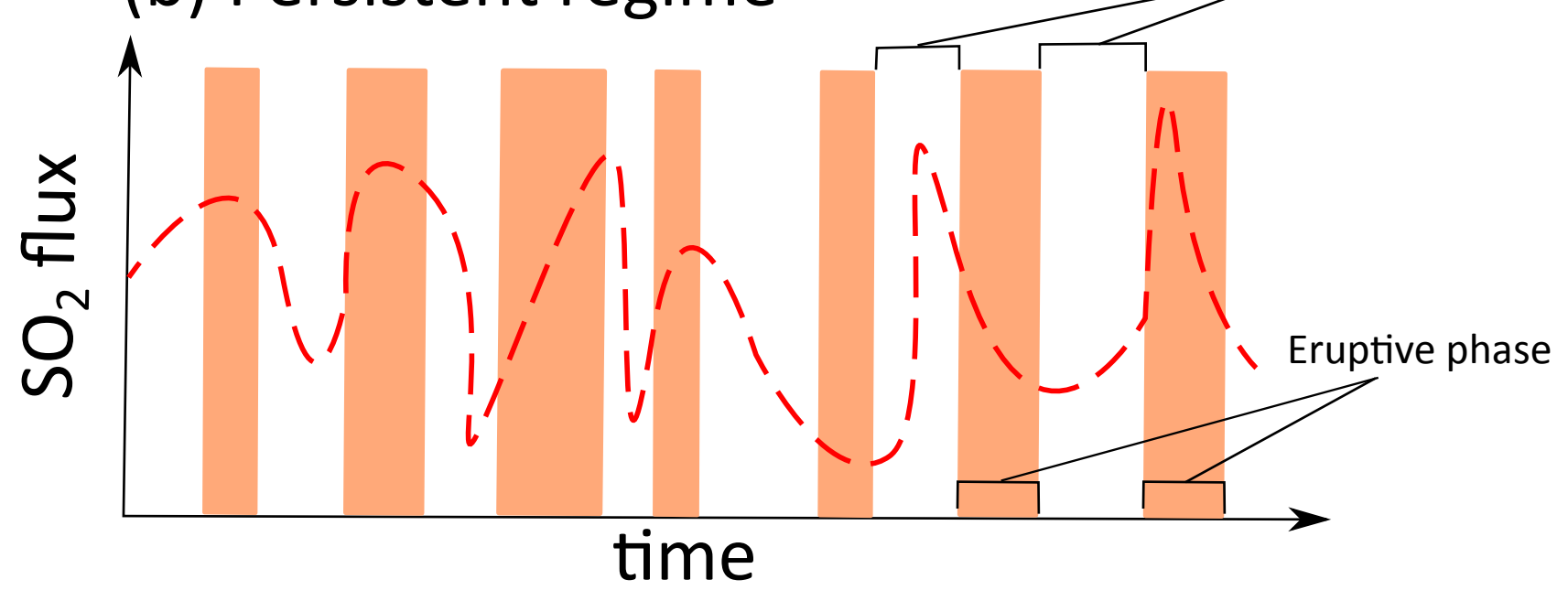

\section{(c) Mixed regime}

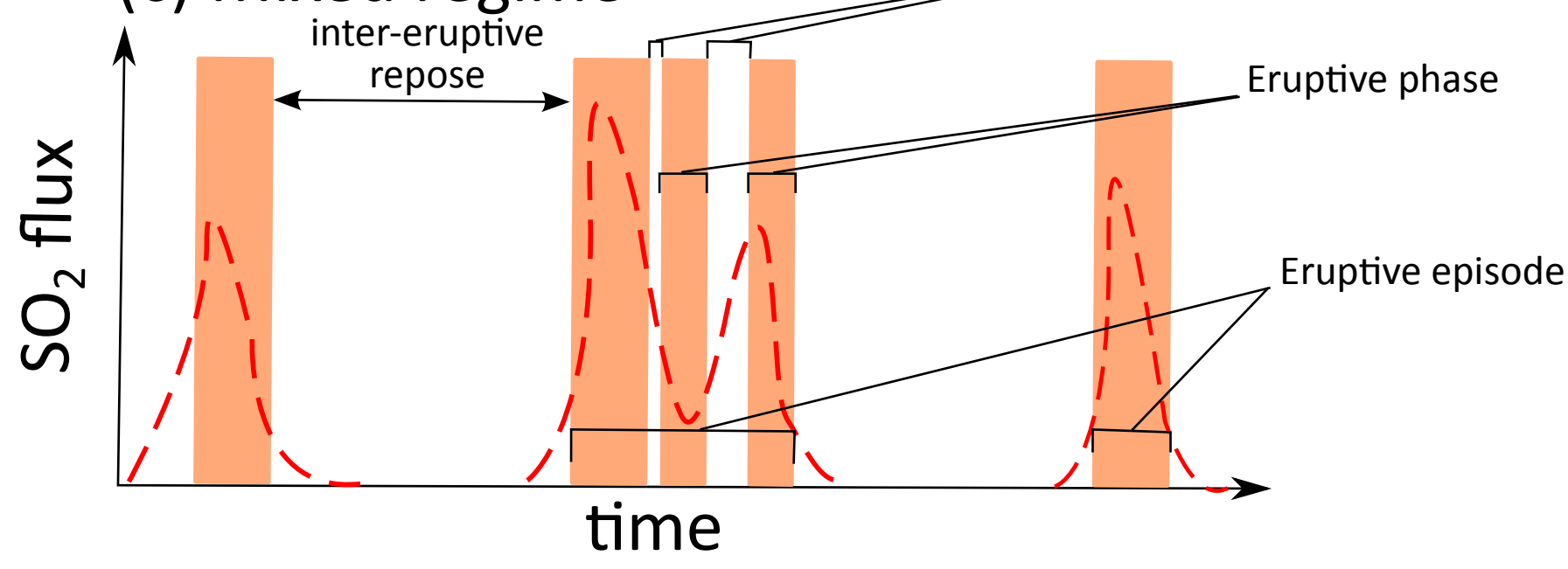

\section{time}

Lava extrusion

(on or off)

- - $\mathrm{SO}_{2}$ flux 


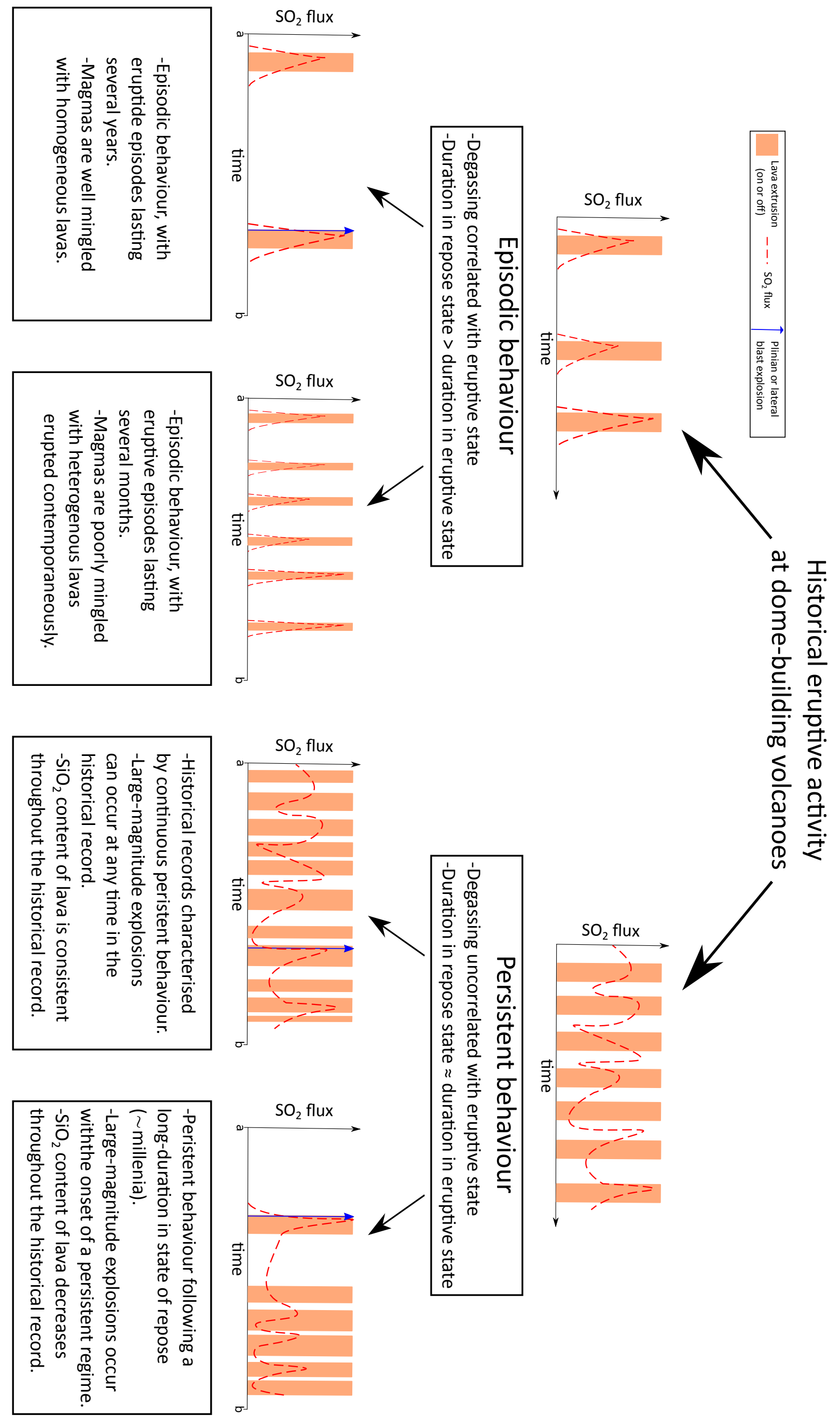


NUMBER OF EARTHQUAKES PER WEEK
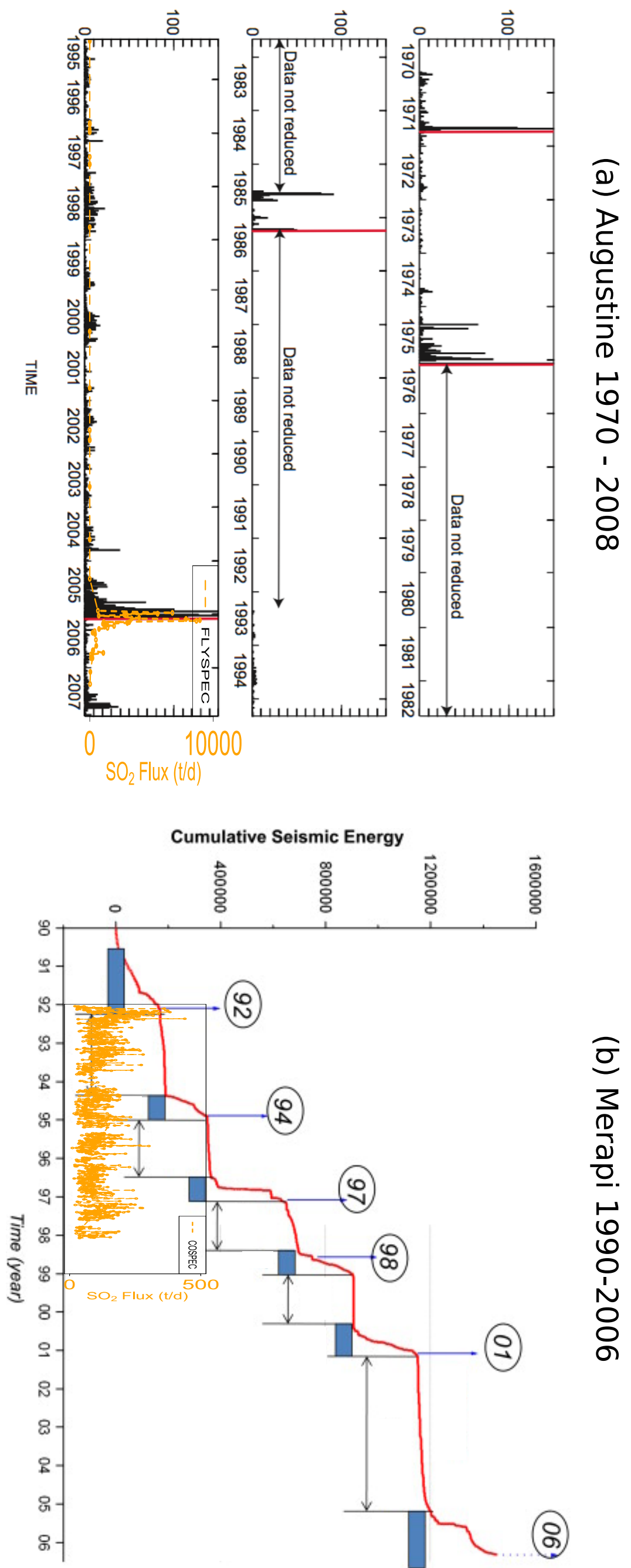


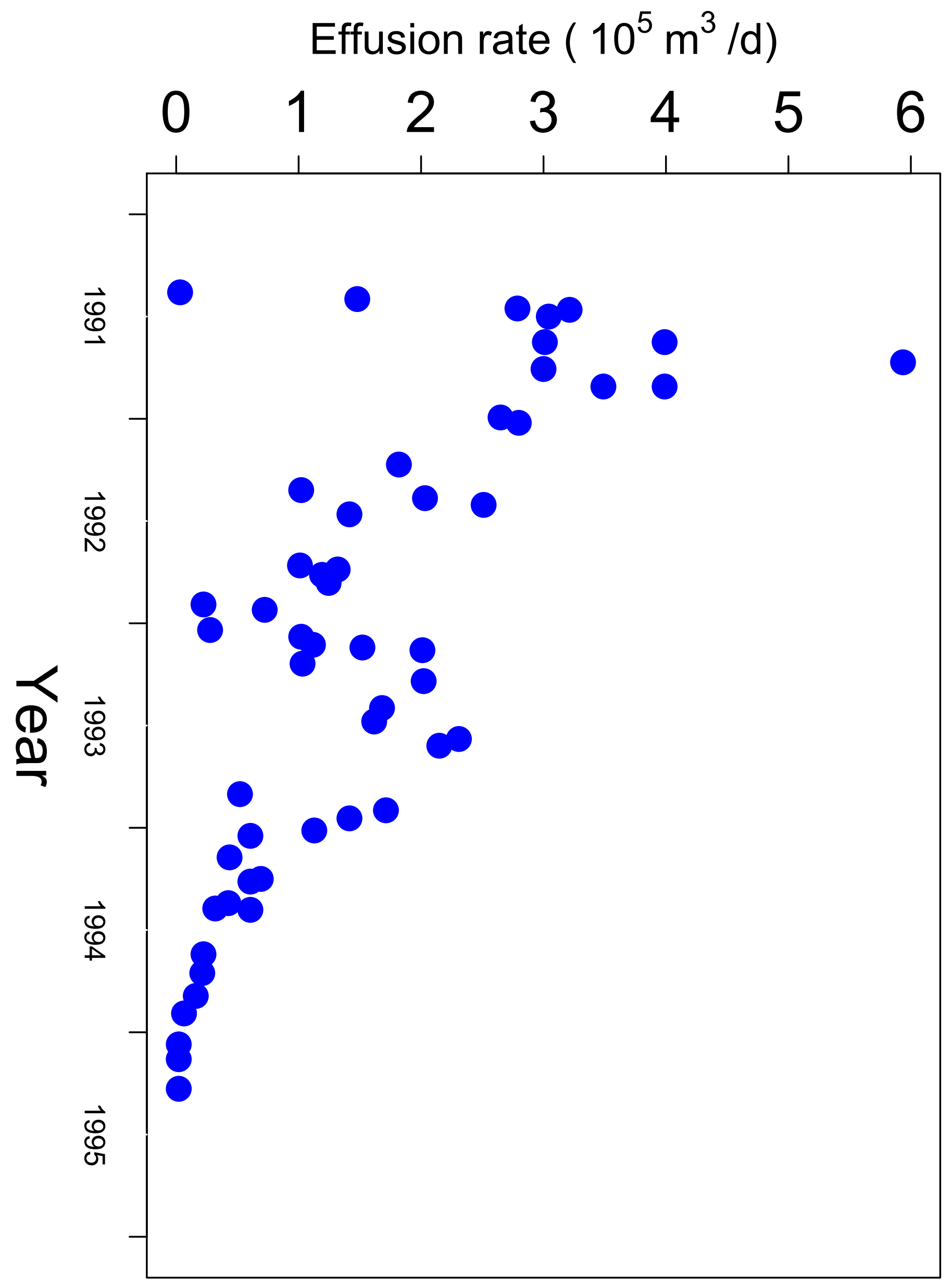


Average extrusion rate $\left(\mathrm{m}^{3} \mathrm{~s}^{-1}\right)$

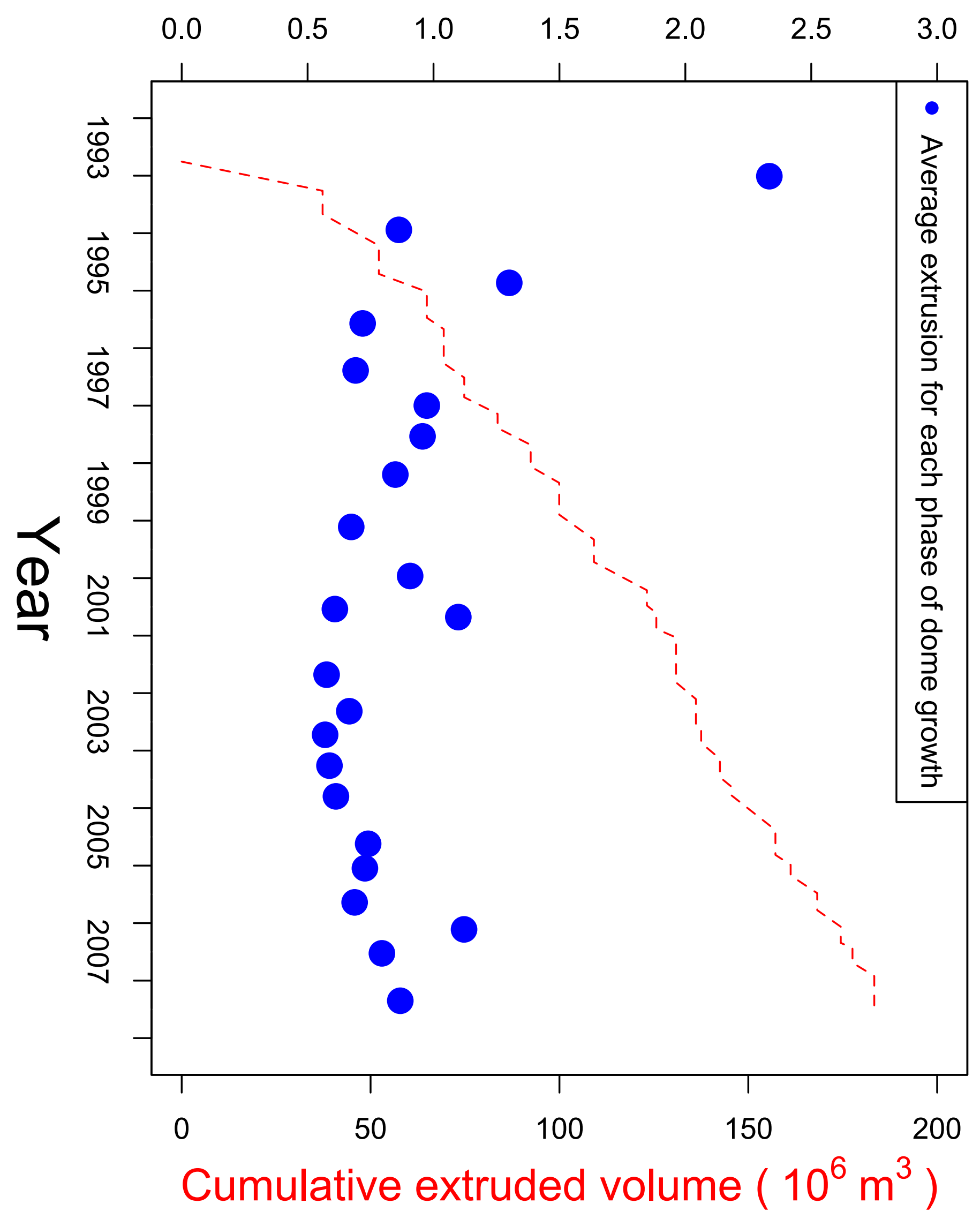




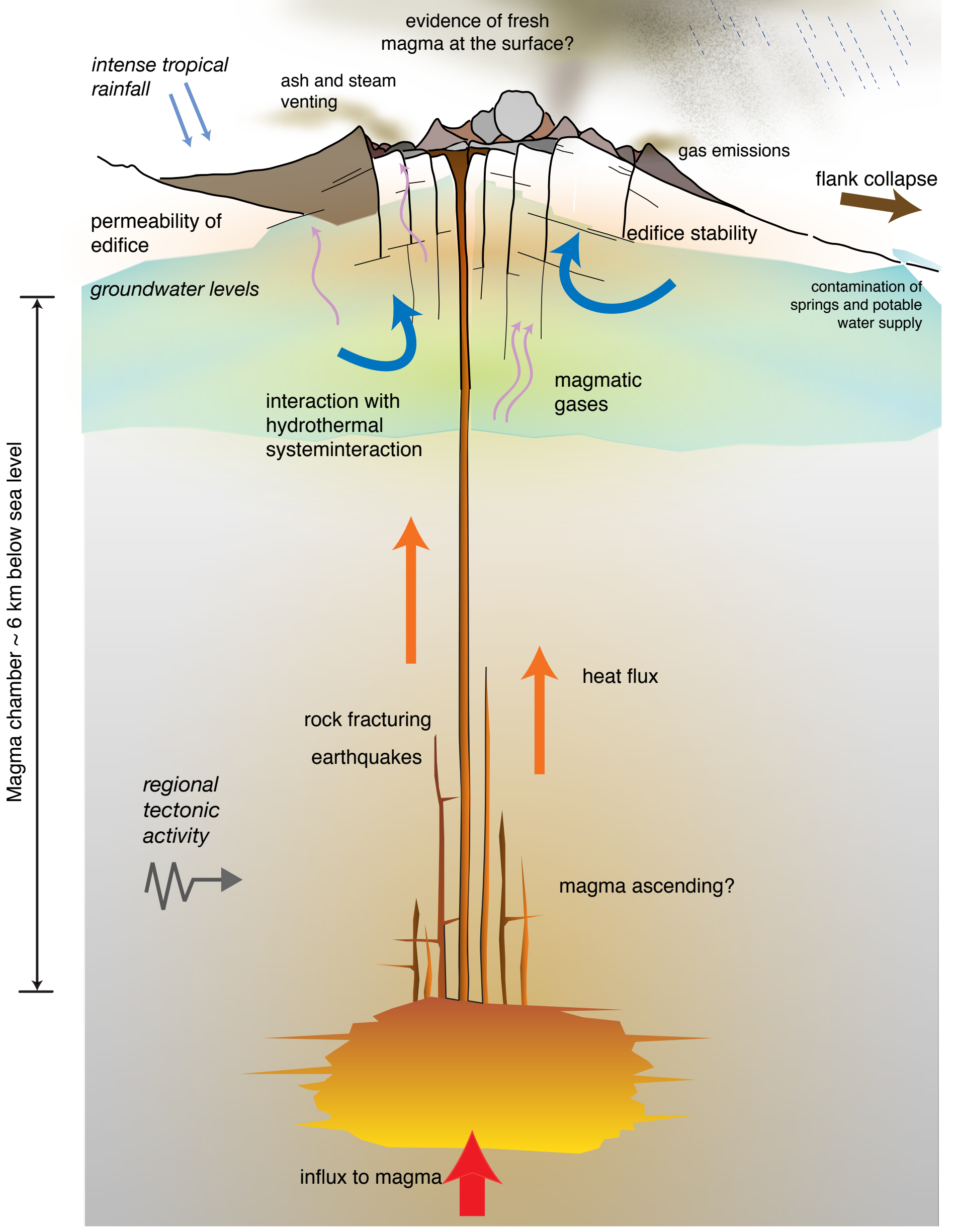



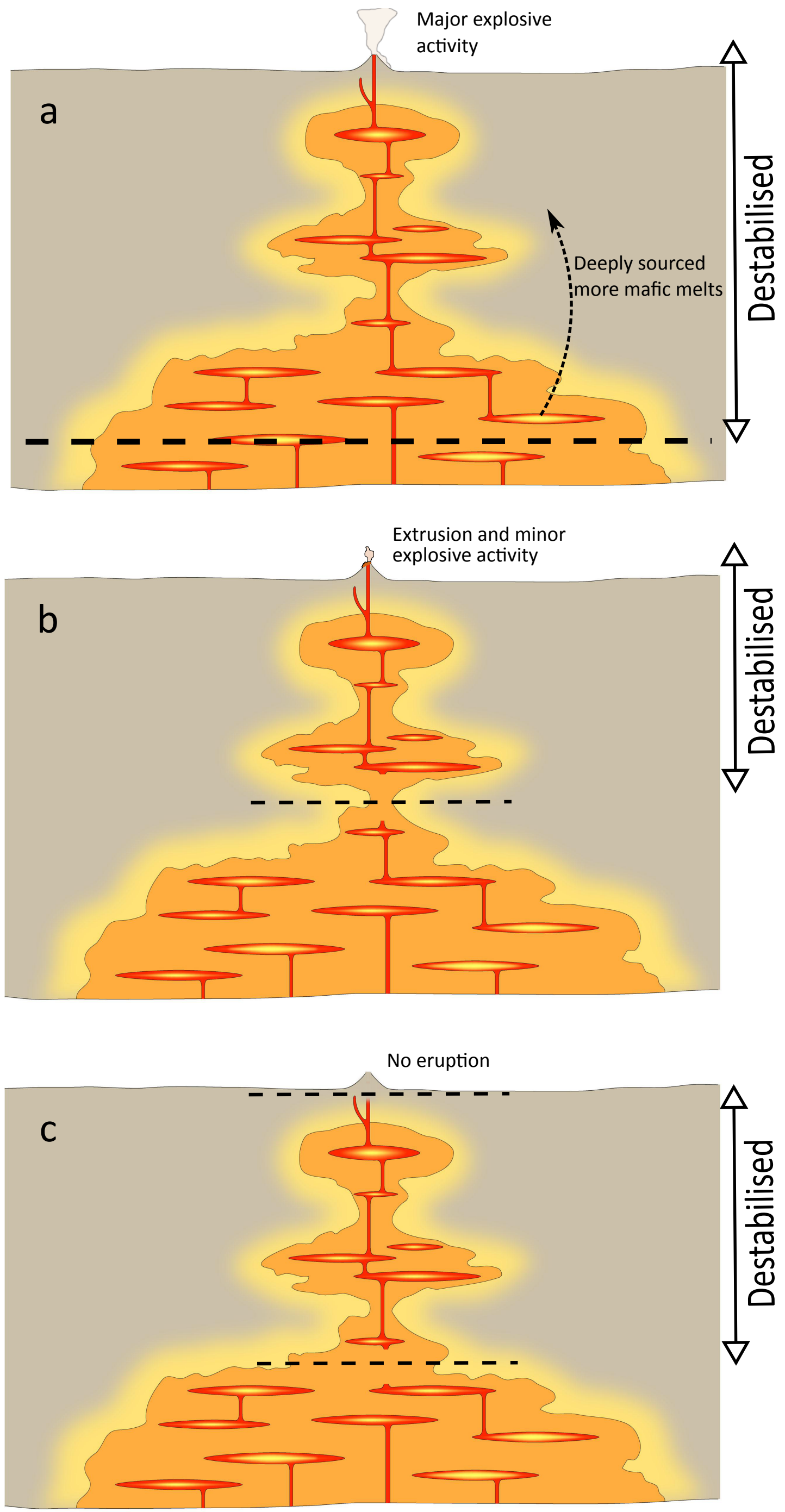